
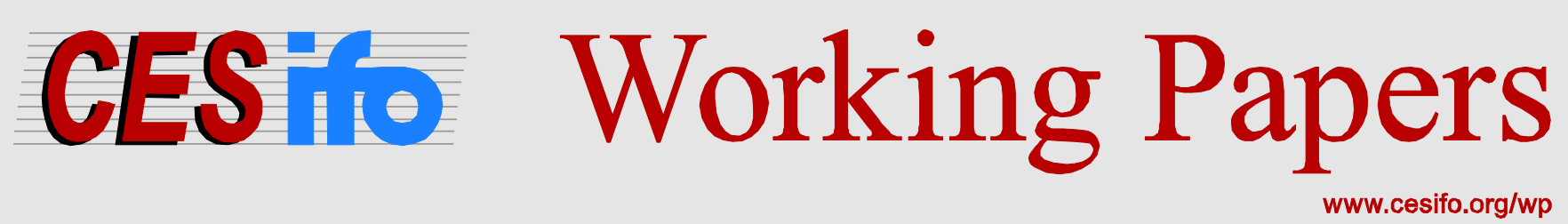

\title{
Ease vs. Noise: On the Conflicting Effects of Transportation Infrastructure
}

\author{
Gabriel M. Ahlfeldt \\ Volker Nitsch \\ Nicolai Wendland
}

CESIFO WORKING PAPER NO. 6058

CATEgORY 1: PUBLIC FinANCE

August 2016

An electronic version of the paper may be downloaded

- from the SSRN website:

- from the RePEc website:

- from the CESifo website: www.SSRN.com

www.RePEc.org

www.CESifo-group.org/wp

ISSN 2364-1428 


\title{
Ease vs. Noise: On the Conflicting Effects of Transportation Infrastructure
}

\begin{abstract}
Many transport technologies cause a "not-in-my-backyard" (NIMBY) reaction of locals in that they often oppose the nearby location of necessary infrastructure despite benefiting from greater mobility. We employ quasi-experimental research methods to disentangle the offsetting noise and accessibility effects of one technology of mass transit, metro rail, analyzing land price effects of the opening of the first German electrified metro rail line in Berlin in 1902. Examining a long-run micro-geographic data set, we find that, ceteris paribus, a $1 \mathrm{~km}$ reduction in distance from the nearest station increases land prices (house prices) by $21 \%$ (5\%), while a $10 \mathrm{db}$ increase in noise depreciates land prices (house prices) by $5 \%(1 \%)$. We show that these effects are underestimated by $40 \%$ (access) to $80 \%$ (noise) if they are not estimated conditional on each other. A complementary analysis of recent property transactions data suggests that preferences for accessibility have remained quite stable over the 20th century, while noise sensitivity increased substantially. The case for constructing underground as opposed to elevated rail lines is therefore stronger today than a century ago.
\end{abstract}

JEL-Codes: R120, R140, R410, N730, N740.

Keywords: accessibility, noise, land price, difference-in-differences, regression discontinuity.

\author{
Gabriel M. Ahlfeldt \\ London School of Economics and Political Sciences (LSE) \\ London / United Kingdom \\ g.ahlfeldt@lse.ac.uk
}

\author{
Volker Nitsch \\ Darmstadt University of Technology \\ Darmstadt / Germany \\ nitsch@vwl.tu-darmstadt.de
}

\author{
Nicolai Wendland \\ Touro College Berlin \\ Berlin / Germany \\ wendland@urbancontext.org
}

\section{Version: August, 2016}

We thank seminar and conference participants in Berlin (Humboldt), Barcelona (UEA), Heidelberg, Miami (UEA), Orléans, Toulouse (SEA), Vaduz (VfS), Wuerzburg, and Zurich (KOF) and especially Kristoffer Möller, Jos van Ommeren, Michael Pflüger, and Sevrin Waights for helpful comments and suggestions. Kristoffer Möller and Sevrin Waights provided outstanding help with the compilation of the data set. Sascha Möbius and Neele ReimannPhillip also provided excellent research assistance. We also thank the Berlin Committee of Valuation Experts and the Senate Department for Urban Development and the Environment for providing property transaction data. The German Science Foundation (DFG project code NI 938/2-1) and the Fritz-Thyssen-Foundation (project code AZ.10.10.2.070) are acknowledged for financial support. The usual disclaimers apply. 


\section{Introduction}

The (exact) routing of transportation infrastructure is often a matter of great public dispute. On the one hand, access to public transportation allows easy travel to other locations. Within cities, for instance, proximity to public infrastructure provides opportunities for commuting to other neighbourhoods, in particular the central city. As a result, areas around public transport stations from which people can then walk to their homes or their jobs often turn out to be particularly valuable (Baum-Snow \& Kahn, 2000; Gibbons \& Machin, 2005). More generally, infrastructure developments have the potential to significantly affect the spatial structure of cities, e.g., by attracting firms and residents to suburbs (Baum-Snow, 2007; Baum-Snow, Loren Brandt, Henderson, Turner, \& Zhang, 2012). Across cities, evidence suggests that a well-developed transport infrastructure enhances trade (Donaldson, 2015; Duranton, Morrow, \& Turner, 2013) and promotes economic growth (Banerjee, Duflo, \& Qian, 2012; Duranton \& Turner, 2012). Often, there is fierce competition between communities regarding the location of motorways, railway stations and airports.

On the other hand, transportation is typically associated with local disamenities (e.g. Boes \& Nüesch, 2011; McMillen, 2004; J. P. Nelson, 2004). Depending on the technology, the operation of transportation infrastructure may imply noise pollution, poorer air quality or other forms of environmental damage. ${ }^{1}$ Consequently, neighbourhoods often strongly oppose the location (or expansion) of transport infrastructure in their immediate proximity (Ahlfeldt \& Maennig, 2015), a phenomenon that is typically referred to as a NIMBY (Not In My Backyard) attitude (Fischel, 2001). Given these conflicting interests and the typically large public investments that are involved in transport infrastructure projects, there is substantial interest, both among policy-makers and economists, in a profound understanding of the related (local) costs and benefits.

In this paper, we study the offsetting positive and negative effects of a standard and widely used transportation technology, metro rail. In particular, we examine the opening of the first German electrified metro rail line, the Line A (or Stammstrecke) in Berlin in 1902, to disentangle the positive accessibility effects from the negative effects related to noise, using programme evaluation techniques. We complement the historic analysis with a hedonic analysis of contemporary metro rail effects. While well-identified estimates of external costs associated with rail noise, holding accessibility benefits constant, are rare, such estimates are important to better understand whether the extra cost for building an underground line are economically justified and fiscally feasible.

1 It has also been argued that mass transit attracts criminal activity (Phillips \& Sandler, 2015). 
Following a large literature in urban and public economics, we infer the value of the countervailing non-marketed externalities from capitalization into real estate prices (Chay \& Greenstone, 2005; Davis, 2004; Greenstone \& Gallagher, 2008; Linden \& Rockoff, 2008; Oates, 1969; Rosen, 1974; Rossi-Hansberg, Sarte, \& Owens, 2010). This approach is derived from the spatial equilibrium assumption in bid-rent theory, one of the workhorse tools in urban economics (Alonso, 1964; Mills, 1967; Muth, 1969). Essentially, it is argued that the value of (urban) land must offset all utility and productivity enhancing or depreciating factors, including noise and accessibility, if households are mobile and markets are competitive. The revealed preference approach is a popular tool in social cost-benefit analyses, which are, in many settings, the preferred method to evaluate welfare effects of public policies (Osborne \& Turner, 2010).

Reviewing the literature, a number of studies have analyzed the property price effects of transportation infrastructure (e.g. Bajic, 1983; Baum-Snow \& Kahn, 2000; Bowes \& Ihlanfeldt, 2001; Damm, Lerner-Lam, \& Young, 1980; Dewees, 1976; McDonald \& Osuji, 1995; Voith, 1993). Recent applications focus, in particular, on the property price effects of transport innovations, e.g. improvements of a road or rail network, to achieve better identification (Ahlfeldt, Moeller, \& Wendland, 2015; Billings, 2011; Gibbons \& Machin, 2005; Hurst \& West, 2014; McMillen \& McDonald, 2004; Xu, Zhang, \& Zheng, 2015). Overall, the findings suggest that transport infrastructures (and railways in particular) are typically associated with an increase in local property values. $^{2}$

On transport-related disamenity effects, there is solid evidence that aircraft noise depreciates property prices (Ahlfeldt \& Maennig, 2015; Boes \& Nüesch, 2011; J. P. Nelson, 2004; Pope, 2008). In similar fashion, high environmental quality, e.g., clean air or water, is typically associated with positive capitalization effects (Harrison \& Rubinfeld, 1978; Leggett \& Bockstael, 2000; J. P. Nelson, 1978), as are unspoilt natural spaces (Gibbons, 2015; Tyrväinen \& Miettinen, 2000). The literature is sparser and less conclusive, however, on the capitalization effects of rail noise. Still, there is some evidence suggesting that rail may have negative property price effects at a highly localized level, possibly due to noise (e.g. Al-Mosaind, Dueker, \& Strathman, 1993; Debrezion, Pels, \& Rietveld, 2010; A. C. Nelson, 1992).

We contribute to the literature in a number of important respects. First, we explicitly disentangle the positive effects of rail access from the negative effects of rail noise in a causal analysis of rail capitalization effects. Therefore, we go beyond most of the existing work that typically focuses on the aggregate (or net) effect of countervailing rail externalities. In doing so, we also examine the

2 The literature is surveyed in, among others, Bartholomew and Ewing (2011), Debrezion, Pels, and Rietveld (2007), Gibbons and Machin (2008), and Wrigley and Wyatt (2001). 
degree of bias that arises when accessibility effects are estimated without controlling for noise effects and vice versa.

Second, we employ a particularly demanding identification strategy that not only controls for unobserved time-invariant characteristics of locations in price levels, but also uses a counterfactual that takes into account heterogeneity in growth trends before the new line was announced. Specifically, our pre-trend weighted (PTW) difference-in-differences (DD) estimator minimizes the conditional correlation between pre-announcement trends in the outcome variable (property prices) and multiple continuous treatment variables (proximity to the station and rail noise). Consequently, we minimize the risk that unobserved trends in property prices correlated with station access or rail noise confound our estimates.

Third, we combine a long-run micro-geographic panel data set with a DD estimator that features time-varying treatment effects, allowing us to explore how expected amenity and disamenity effects gradually capitalized into property prices before and after the completion of the project. As a result, we also gain interesting insights into how the completion of the rail line impacts on price levels and trends.

Fourth, our spatially highly disaggregated, micro-geographic data set allows us to exploit a sharp discontinuity at the point where the tracks enter a tunnel to vanish beneath the surface. We use a combination of Regression Discontinuity Design (RDD) and DD approach to assess the pure noise effect on adjacent land prices. We use these strongly identified estimates of the noise effect as an over-identification test for our PTW DD estimates.

Fifth, we provide one of the few analyses of rail capitalization effects into land prices (e.g. Ahlfeldt, Moeller, et al., 2015; Coffman \& Gregson, 1998) whereas most previous studies have looked at price responses of properties or housing units. The analysis of land prices comes with the advantage of not having to control for structural characteristics. In addition, because land is scarce in an urban context and provided (almost) inelastically, adjustments in land prices can be assumed to be purely driven by demand. The analysis of house price effects, in contrast, may be mitigated by supply responses if the demand curve is locally downward sloping because of imperfect mobility and idiosyncratic location preferences (Hilber \& Vermeulen, 2015).

Sixth, and most notably, we analyse the opening of a rail line in a historic context, about a century ago. Being the first of its kind in Germany, the line was a true innovation and accompanied by considerable uncertainty regarding potential local costs and benefits. Therefore, the analysis of the adjustment path of land prices over time is particularly interesting. Moreover, our plot level data set is unmatched in its spatial detail in a historical context, containing up to 11,817 annual observations. Since a comparison with contemporary analyses of rail infrastructure projects yields in- 
sights into how the valuation of rail amenities and disamenities has changed over time, we complement our historic analysis with a contemporary analysis using recent property transactions data.

Seventh, in analysing the welfare case of building elevated or underground metro lines, we provide novel auxiliary findings that are interesting in their own right. We estimate the per $\mathrm{km}$ cost of an underground metro line at the beginning of the 20th century to be three times that of an elevated line, which is substantially larger than the contemporary rule-of-thumb factor of two. We also find that, over a period of about 130 years, the average annual nominal land price growth rate was about 5\% in Berlin and, therefore, typically within the range of the opportunity cost of capital (central bank interest rates). Taking into account property price inflation, we estimate the real property tax in Berlin to be about $0.3 \%$, which is just about one fifth of the official rate applied to historic land values.

Previewing our results, we find that, ceteris paribus, a $1 \mathrm{~km}$ reduction in distance to the nearest station increases land prices (house prices) by $21.1 \%$ (5.3\%) while a $10 \mathrm{db}$ increase in noise depreciates land prices (house prices) by $5.0 \%(1.3 \%)$. Our estimates imply that, at stations, the countervailing effects of the infrastructure just about offset each other. Moreover, we show that if the effects are not estimated conditional on each other, they are underestimated by $40 \%$ (access) to $80 \%$ (noise). We validate our noise PTW DD estimates by particularly well-identified RDD DD estimates which exploit the discontinuity in noise exposure at the tunnel entrance. A comparison to contemporary rail effects suggests that the value of access to metro rail has remained fairly constant over time, while sensitivity to noise has increased substantially. The case for constructing underground rail lines in an urban setting is therefore stronger than the time when Berlin's Line A was constructed.

The remainder of the paper is organized as follows. In Section 2, we discuss the historical background and present our data, followed by a description of our empirical strategy for the historic analysis. The heart of our paper is Section 4, which presents the empirical results along with a complementary contemporary analysis and a discussion of welfare and fiscal policy implications. Section 5 provides a brief conclusion.

\section{Historical background and data}

\subsection{History}

In 1879, the German founder and inventor Werner von Siemens presented the first fully electrified experimental railway at the internationally renowned trade and industrial exhibition (Gewerbeausstellung) in Berlin. In view of the phenomenal success of his invention, with follow-up 
presentations in Brussels, Frankfurt, Copenhagen, London and Moscow, he eagerly worked towards a quick implementation of this technology for the city of Berlin. By 1891, the company Siemens \& Halske had proposed a densely linked network of various lines to connect the inner core of "old Berlin" with its - then - surrounding municipalities. ${ }^{3}$

According to initial plans, the network was to be built entirely on elevated tracks, mainly because of strict regulation of underground activities due to construction works on the new canalization system led by James Hobrecht. Given the original structure of the inner city, however, with its small alleys and winding streets, this plan appeared to be problematic from the beginning. Moreover, according to existing commuting patterns, the construction of a north-south connection would have been the most desirable project in order to ease the traffic on many heavily used streets. However, Berlin's city government (Magistrat) strictly rejected this idea in fear of the unforeseeable consequences regarding the appearance of one of Berlin's most prominent northsouth boulevards, the Friedrichstrasse (Domke \& Hoeft, 1998).

Thus, in 1895, a concession was granted for the establishment of a less favored east-west connection. The line was to connect the eastern parts of Berlin, at the station Warschauer Brücke, and the wealthy western city of Charlottenburg, at the station Zoologischer Garten, running exclusively on elevated tracks. Built along another of Berlin's major boulevards, this was considered the only possible routing for that line. At that time, however, the Magistrat of Berlin considered the whole project to be too risky and non-profitable, deciding not to participate in its final execution (Baltzer, 1897). Therefore, in 1897 (only five years before the inauguration of the line), Siemens \& Halske founded the Elevated Railway Company (Hochbahngesellschaft) in cooperation with the Deutsche Bank to guarantee the funding.

The construction began immediately, starting from the eastern parts. However, Berlin residents quickly realized the viaduct's unpleasant appearance. Also, Berlin's municipal planning and building control office, with its newly appointed head Friedrich Krause, was no longer generally opposed to plans for the construction of underground lines. As a result, the city of Charlottenburg managed to ensure, in a last minute move, that the tracks ran beneath the street surface once the line reaches its boundaries. The decision led, once more, to a change of routing plans along major parts of the line, with negotiations about possible courses starting less than three years before the opening of the line.

3 Social and economic integration among the city of Berlin and its surrounding areas had been constantly growing, especially since the 1870s. In 1912, the areas formally established an economic partnership. Later, in the grand amalgamation in 1920, Berlin was officially merged with seven other cities, 59 rural municipalities (Landgemeinden), and 27 rural districts (Gutsbezirke) to become the new city of Greater Berlin (Groß-Berlin). 
The routing was finally determined by the intentions of two major players. Having recently bought large tracts of land in Charlottenburg's Westend district, Deutsche Bank sought to connect these areas to the new line in order to benefit from an increase in land values (Erbe, 1987). The city of Charlottenburg, in contrast, preferred the tracks connecting areas further to the north. In the end, the line was inaugurated in 1902 and called "Line A" (Linie A or Stammstrecke). The final routing, depicted in Figure 1, was later described by historians as an outcome of agreements and accidents (Bousset, 1935).

Fig. 1. Routing of Berlin's first metro line (Linie A)

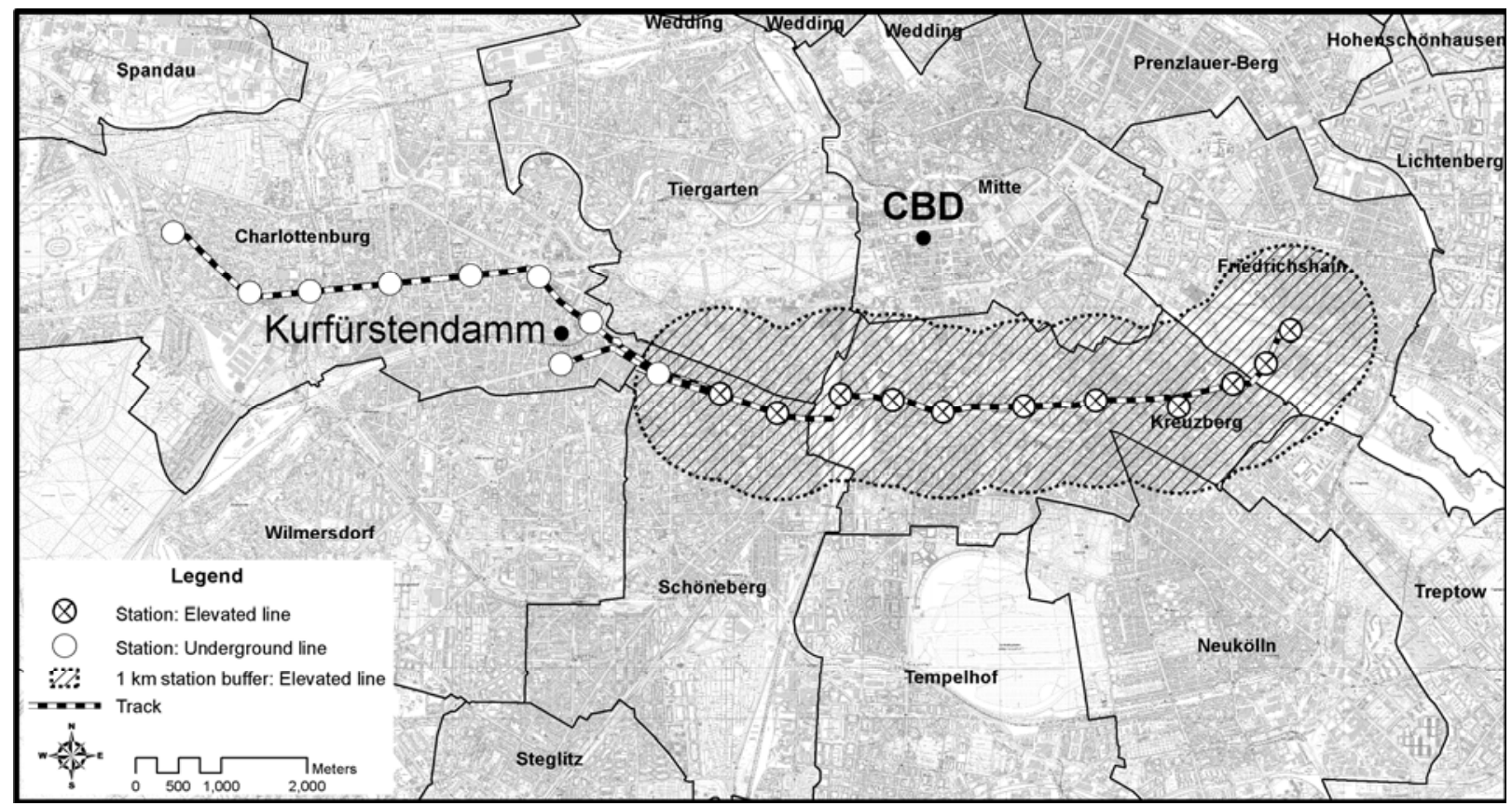

Notes: Own illustration using the Urban Environmental Information System of the Berlin Senate Department (Senatsverwaltung für Stadtentwicklung Berlin, 2006). CBD is the central business district. Kurfürstendamm is a major sub-centre.

\subsection{Data}

\section{Land Prices}

Our measure of land price is extracted from various editions $(1881,1890,1896,1900,1904,1910$, and 1914) of assessed land value maps created by the renowned technician Gustav Müller in cooperation with official planning authorities. Müller's maps provide data at a remarkably disaggregated level of individual plots. The stated objective was to provide official and representative guides for both private and public investors participating in Berlin's real estate market. While Müller himself did not describe in detail the exact procedure of land valuation, the imperial valuation law (Reichsbewertungsgesetz) of the German Reich contained a strict order to use capital values for the assessment of commercial plots based on fair market prices. In line with the valuation laws for commercial land, Müller claims that his assessment refers to the pure value of land, which 
is adjusted for all building and even garden characteristics. He also corrected values for specific location characteristics such as single and double corner lots, subsoil and courtyard properties.

Müller's maps are by now an established data source. They have been used, among others, by Ahlfeldt et. al (2015), who also provide an extensive data appendix that describes in detail the nature of the data. More notably, the data are directly comparable to the more recent Berlin land price data (1928, 1936, 1986, 2006) used by Ahlfeldt, Redding, Sturm, and Wolf (2015); they also share many similarities to Olcott's Chicago land values, ${ }^{4}$ which have been used in studies such as Berry (1976), Kau and Sirmans (1979), McDonald and Bowman (1979), McMillen (1996), McMillen and McDonald (2002), Mills (1969), and Yeates (1965).

In contrast to previous analyses based on Müller's data, we exploit its full spatial detail at the parcel level. To preserve the highly disaggregated nature of the original data, we digitize every single data point within a buffer of $1 \mathrm{~km}$ around the newly built elevated tracks within a GIS environment. After creating a balanced panel for the final analyses, this leaves us with a total of 45,947 observations for seven points in time.

\section{Noise}

To assess the disamenities from increasing noise levels, we consult a highly disaggregated map, obtained from the Berlin Senate Department for Urban Development, which contains 2007 estimates of the continuous sound level by the source of noise at a 10x10 meter grid. Given that the built-up structure within the affected area remained virtually unchanged after the inauguration of the line, 5 it can reasonably be argued that contemporary noise levels reflect the dissemination of sound about 100 years ago.

\section{Elevated train line and metro}

Historical network plans provide sufficient information on tracks and individual stations along the route to extract and digitize the whole line. ${ }^{6}$ The elevated section of the line consists of 11 stations, while the entire line (including the underground section) consists of 20 stations with a total length of $15.2 \mathrm{~km}$.

4 Olcott's land values blue book of Chicago and suburbs was published regularly by G. C. Olcott's \& Co., Inc. from the 1910s to the 1990s.

5 Note that for very few plots, where the building structure changed, we impute historic noise levels using adjacent plots.

6 Network plans are also available online; see, for instance, http://www.berlineruntergrundbahn.de and http://www.berliner-verkehr.de. 


\section{Empirical strategy}

In this section, we describe the empirical strategy for the historic analysis of the effects of the establishment of Line A. We proceed in two steps. First, we run a conventional DD analysis of the elevated section of the rail line where the effects of noise and access to stations can be identified from variation in land values over time. In a next step, we perform a micro study of the area around the tunnel entrance from the elevated to the underground sections of the line which provides discontinuous variation in noise over time. This variation allows for a particularly robust identification of noise effects, controlling for access to the station. Specifically, we argue that estimated noise effects from the discontinuity design that are in line with the DD estimate will indicate that our DD estimates are well-identified; they not only lend credibility to the DD noise effect estimates but also to our accompanying DD estimates of the access effect.

\subsection{Difference-in-differences}

Our baseline empirical strategy combines hedonic (Rosen, 1974) and difference-in-differences (DD) methods (Ashenfelter \& Card, 1985). We employ the hedonic approach to express the price of a parcel of land as a function of various attributes, including rail noise and rail access, and their implicit prices. The DD method then allows us to identify a treatment effect (e.g., of rail access or rail noise) by differentiating across space (different degrees of exposure) and time (before and after exposure). Our baseline empirical specification takes the following form:

$$
\ln \left(P_{i t}\right)=f\left(S_{i}, t, N_{i t}\right)+X_{i t} b_{t}+\mu_{i}+\theta_{t}+\varepsilon_{i t},
$$

where $P_{i t}$ is the land price of a parcel $i$ at time $t, \mu_{i}$ is a parcel fixed effect controlling for unobserved time-invariant heterogeneity onto which we cluster standard errors (Bertrand, Duflo, \& Mullainathan, 2004), and $\theta_{t}$ is a year fixed effect controlling for common macroeconomic shocks. $X_{i t}$ is a vector of time-invariant control variables interacted with year effects such that $b_{t}$ is a matrix of year-specific implicit prices. $f\left(S_{i}, t, N_{i t}\right)$ is a treatment function that expresses the effects of the metro line as a function of the straight-line distance to the nearest station $S_{i}$, the emitted noise $N_{i t}$, and time $t$.

While the opening date of the line (1902) is known a priori, the exact temporal structure of the capitalization of the effects of the line into land prices is not. Capitalization will occur gradually rather than immediately if the service is an experience good and it takes some time before transit riders adjust their behavior to take full advantage of the new option. If the semi-strong (or strong) efficient market hypothesis (Fama, 1970) holds, markets will respond to all information made publicly available, which can result in anticipation effects as soon as the new line is announced. In 
setting up our DD model, we begin by estimating a series of time-varying treatment effects that reveal the temporal adjustment path in a flexible manner.

$$
f\left(D_{i}, N_{i}, t\right)=\sum_{z=1890,1896, \ldots}^{1914}\left[\alpha_{z}^{S} S_{i} \times(t=z)_{t}+\alpha_{z}^{N} N_{i} \times(t=z)_{t}\right]
$$

where $(t=z)_{t}$ is an indicator variable, which takes the value of one if the condition is met and zero otherwise. Parameters $\alpha_{z}^{S}$ and $\alpha_{z}^{N}$ each represent an individual DD parameter reflecting how land prices for parcels exposed differently to noise and accessibility effects (first differences) changed from 1881 to year $z$ (second differences).

We note that, because there was no metro rail noise prior to the elevated train line, our noise measure reflects the increase in noise due to the elevated rail line (such that $N_{i}=\Delta N_{i}$, where $\Delta N_{i}$ is the before-after change in noise). Therefore, $\alpha_{z}^{N}$ provides a first-difference estimate of the effect of rail noise on land prices that can be interpreted as a hedonic implicit price. In contrast, $\alpha_{z}^{S}$ gives the change in the hedonic implicit price of distance to station locations from year 1881 to year $z$, i.e. $\alpha_{z}^{S}=\delta_{z}^{S}-\delta_{1881}^{S}$, where $\delta_{z}^{S}$ is the hedonic implicit price in given year $z$. $\alpha_{z}^{S}$ can still be interpreted as the hedonic implicit price of proximity to a station $\delta_{z}^{S}$ since in 1881 the stations could not be anticipated and, thus, $\delta_{1881}^{S}=0$.

Informed by this analysis, we then estimate an extended DD model which provides a before-andafter comparison, controlling for the effects during an identified adjustment period.

$$
\begin{aligned}
f\left(D_{i}, N_{i}, t\right)= & \alpha^{S}\left[S_{i} \times(t>1902)_{t}\right]+\alpha^{N}\left[N_{i} \times(t>1902)_{t}\right] \\
& +\sum_{A}\left[\alpha_{A}^{D} S_{i} \times(t=A)+\alpha_{A}^{N} N_{i} \times(t=A)\right]
\end{aligned}
$$

where $(t>1902)_{t}$ is an indicator variable taking the value of one for years after the line opening and $(t=A)_{t}$ is defined similar to $(t=z)_{t}$ in equation (2). In $A$, we include all years during which land prices appear to be adjusting to a new equilibrium. Note that compared to dropping those years, controlling for adjustment effects offers the advantage of processing more information for identification of covariate effects $(X)$ and fixed effects $\left(\mu_{i}, \theta_{t}\right)$.

The critical and essentially untestable assumption of any DD analysis is that, in the absence of a treatment, all subjects (irrespectively of the intensity of treatment) would have followed the same trend. A selection problem exists if the treated and the non-treated subjects differ in observable or unobservable dimensions, and these differences imply heterogeneous responses to common shocks. A variety of techniques have emerged to address such problems, many of which aim at weighting observations in such a way that the intensity of treatment becomes orthogonal to observable characteristics. The propensity score matching, for instance, aims at weighting observa- 
tions such that a control group resembles a treatment group in terms of observable characteristics (Rosenbaum \& Rubin, 1983). The synthetic control method creates a synthetic control as weighted combination of non-treated subjects that resembles a treated subject in terms of observable characteristics and the trend observed prior to the treatment, the pre-trend (Abadie \& Gardeazabal, 2003). The coarsened exact matching (Iacus, King, \& Porro, 2011) assigns weights to observations that ensure that pre-trends in an outcome variable are balanced across a treatment group and a control group.

The application of such established matching techniques is complicated in our setting by two factors. For one thing, we estimate the effects of two treatments, station access and rail noise, conditional on each other. For another thing, the intensity of treatment is not dichotomous, but varies continuously in space. In this case, it is not a trivial task to distinguish between subjects that are treated and non-treated in a discrete way.

We, therefore, employ an alternative weighting approach. Using a pre-trend weighted (PTW) DD approach, we seek to find a vector of parcel weights that minimizes the conditional correlations between both treatment variables and the 1881-1890 trend in land prices, a period for which we are confident that the line has not been anticipated. The rationale is that if our treatment measures are uncorrelated with pre-trends they will likely be uncorrelated with trends unrelated to the treatment during the treatment period. We highlight that we have two more pre-opening periods in our data (1890-1896, 1896-1900). It is, thus, possible to evaluate whether the common trends assumption holds using information that was not used in the construction of the weights.

We define the parcel weights as a function of $n$ variables $d_{n}$ of the following form:

$$
W_{i}=\frac{w_{i}}{\sum_{i} w_{i}}, w_{i}=\sum_{n} \theta_{n} k_{n}\left(\lambda_{n}, d_{i n}\right),
$$

where $k_{n}$ is a kernel function, $\lambda_{n}$ is a variable-specific bandwidth and $d_{i n}$ is a vector of pretreatment parcel characteristics, including distance from the central business district (CBD), distance from the Kurfürstendamm (the major western sub-center), and a measure of abnormal growth defined as $\Delta \ln \left(P_{i, 1890}\right)-\overline{\Delta \ln \left(P_{1890}\right)}$, where $\Delta \ln \left(P_{i, 1890}\right)$ is the change in the natural logarithm of land prices from 1881 to 1890 and the upper bar indicates the mean across the distribution. We use a standard Gaussian kernel and bandwidths set according to the Silverman (1986) rule. $^{7}$

7 Formally, the bandwidth is chosen as $\lambda=1.06 \times \sigma N^{-\frac{1}{5}}$ 


$$
k_{n}=\frac{1}{\lambda_{n} \sqrt{2 \pi}} \exp \left(-\frac{1}{2}\left(\frac{d_{i n}}{\lambda_{n}}\right)^{2}\right)
$$

In this setting, our problem becomes finding the vector $\theta_{n}$ that minimizes the conditional correlations of noise and access with the 1881 to 1890 pre-trend in land prices $\left(\Delta \ln \left(P_{i, 1890}\right)\right)$. We determine this vector in a grid search over the parameter space defined by $\theta_{n}(0,0.01,0.02, \ldots 1)$, which equates to $101^{\wedge} 3=1,030,301$ combinations. In particular, we select the combination of parameters $\theta_{n}$ that minimizes the sum of squared partial correlations between our treatment measures (rail noise and station access) and $\Delta \ln \left(P_{i, 1890}\right)$. For each combination, we estimate these partial correlations in auxiliary weighted (by $\left.W_{i}\right)$ regressions of $\Delta \ln \left(P_{i, 1890}\right)$ against standardized measures of rail noise and station access. ${ }^{8}$

By using weighted combinations of (time-invariant) covariates to balance pre-trends across subjects exposed to differing treatment intensities, our approach shares similarities with the synthetic control method (Abadie \& Gardeazabal, 2003). One limitation of our approach is that we do not balance the covariates themselves, but focus exclusively on balancing pre-trends across different intensities of treatment. In this respect, our approach is more similar to the coarsened exact matching (Iacus et al., 2011). The main advantage of our approach, however, is the ability to ensure that the pre-trends are conditionally uncorrelated with multiple treatments of continuously varying intensity.

\subsection{Regression discontinuity}

The specific character of Line A, in combination with the unique, spatially highly disaggregated data available to us, enables us to identify the effect of the noise disamenity using a relatively sharp and discontinuous change in rail noise at the tunnel entrance where the line switches from being elevated to running underground and vice versa. Our empirical approach is inspired by the regression discontinuity design literature (e.g. Basten \& Betz, 2013; Dell, 2010; 2008; Lalive, 2008) and, in particular, work that exploits discontinuous changes at spatial boundaries (Gibbons, Machin, \& Silva, 2013). Since we compare land prices at two sides of a spatial boundary (first difference) and before and after the line opening (second difference), our approach is essentially a DD model, with identification being restricted to a source of discontinuous variation as in the RDD literature. We, therefore, refer to our approach as a RDD-DD model.

8 We run $m$ regressions of the following form $\Delta \ln \left(P_{i, 1890}\right)=c_{m}^{0}+c_{m}^{S} \tilde{S}_{i}+c_{m}^{N} \widetilde{N}_{i}+\varepsilon_{m i}$, where $\Delta \ln \left(P_{i, 1890}\right)$ is the change in log land price from 1881 to 1890 and tilde denotes normalization by standard deviation. In each regression, observations are weighted by $W_{i}$, which depends on the vector $\theta_{n}$. We select the combination of $\theta_{n}$ parameters that minimizes $\sum_{q=(S, N)}\left(\widehat{c_{m}^{q}}\right)^{2}$. 
Again, it should be noted that the agreement to construct the line as an underground line within the boundaries of the city of Charlottenburg, whose authorities opposed the erection of an elevated line, was reached not earlier than three years before the inauguration. Therefore, for the discontinuous change in noise at the tunnel entrance, anticipatory effects are unlikely. Moreover, our RDD-DD model washes out any effect of accessibility and other location characteristics, thereby generating a very precise estimate of the pure rail noise effect. Most notably, our land price data allows us to identify the effect using very small spatial windows from the rail track and the tunnel entrance. Figure 2 illustrates the micro geography around the tunnel entrance, which is right at the intersection of the two dotted lines. Evidently, a 50-meter buffer drawn around the track comfortably covers the boulevard under which the line is routed as well as the front rows of buildings framing the boulevard.

Fig. 2. Micro geography at tunnel entrance

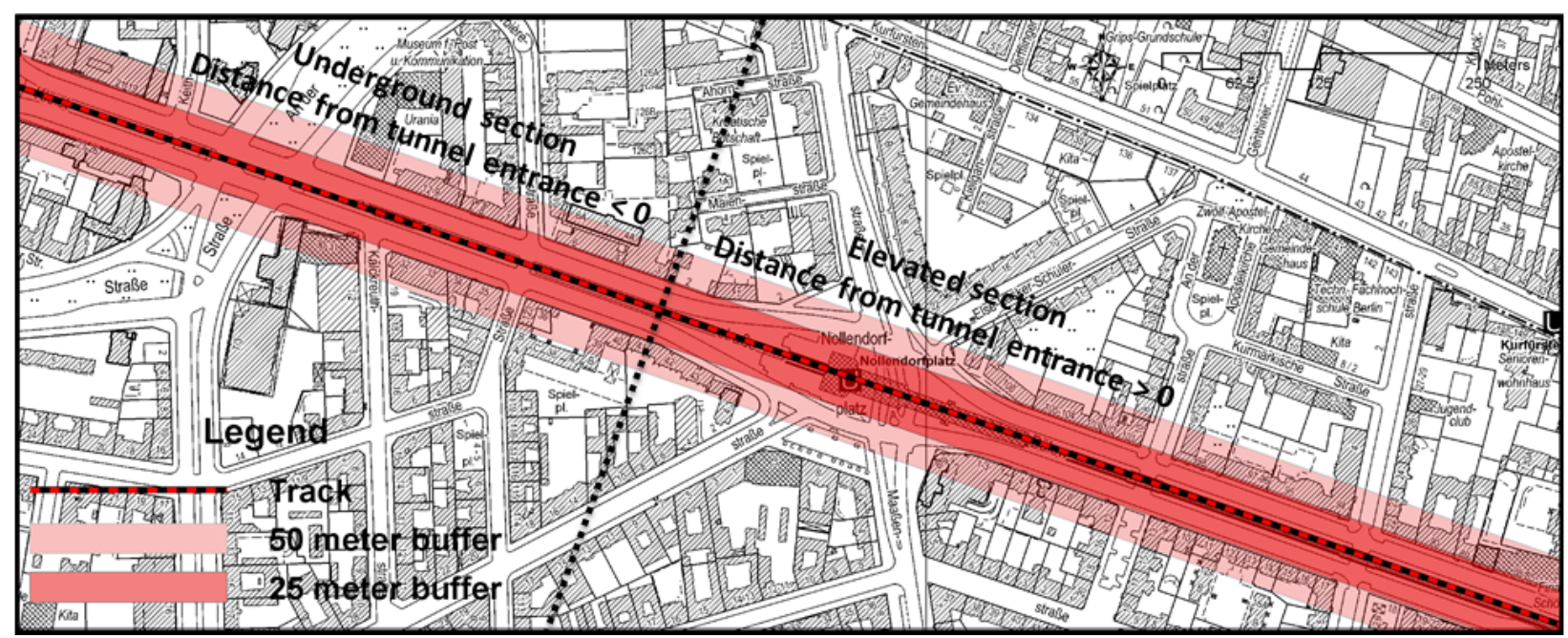

Notes: Dotted line is the orthogonal intersecting with the track at the tunnel entrance. Own illustration using the Urban Environmental Information System of the Berlin Senate Department (Senatsverwaltung für Stadtentwicklung Berlin, 2006).

Our RDD-DD specification takes the following form:

$$
\ln \left(P_{i, 1904}\right)-\ln \left(P_{i, 1900}\right)=\beta\left(D_{i}>0\right)_{i}+\sum_{o} \vartheta^{o} D_{i}^{o}+\sum_{o} \gamma^{o}\left((D>0)_{i} \times D_{i}\right)^{o}+X_{i} b+\varepsilon_{i}
$$

where $D_{i}$ is the running variable defined as the shortest distance from the orthogonal that intersects with the tract at the tunnel entrance (the black dotted line in Figure 2). The variable takes negative values within the underground section and positive values within the elevated section. $(D>0)_{i}$ is a dummy variable taking the value of one if the condition is met, i.e., the parcel falls into the elevated section, and zero otherwise. $o$ defines the polynomial order of the distance trend specification, conditional on which the discontinuity effect is estimated. The coefficient of interest 
is $\beta$ and provides an estimate of the extent to which the exposure of noise emitted by an elevated rail depreciates land prices.

Because our outcome variable is in differences we implicitly allow for arbitrary heterogeneity in time-invariant unobservable location characteristics. The identifying assumption is that only the variable of interest, noise, experiences a discontinuous change at the tunnel entrance from 1900 to 1904 . We allow for arbitrary variation in unobserved characteristics from 1900 to 1904 as well as changes in implicit prices of arbitrary characteristics, but impose the identifying restriction that these changes are smooth in the running variable.

\subsection{Interpretation of estimated implicit prices}

Throughout this paper, we provide causal estimates of rail noise and station access on land prices, i.e., we estimate implicit hedonic prices of these attributes. A particularly attractive feature of using land price data is that we do not have to control for property characteristics. Also, because land is scarce in an urban setting, the price response is unlikely to be affected by a quantity response, which would be a concern with property data if developers could build more densely to meet increases in demand and the demand curve is locally sloping downward (e.g., due to imperfect mobility and idiosyncratic preferences). At the same time, however, our results are not directly comparable to capitalization effects reported in the literature as these effects often refer to house prices (e.g. Gatzlaff \& Smith, 1993; Gibbons \& Machin, 2005; Mieszkowski \& Saper, 1978; J. P. Nelson, 2004).

To allow for a simple micro-founded translation of land price capitalization effects into house price capitalization effects, it is useful to assume a Cobb-Douglas housing production function and a competitive construction sector. Assume that housing services $H$ are produced using the inputs capital $K$ and land $L$ as follows: $H=K^{\alpha} L^{1-\alpha}$. Housing space is rented out at bid-rent $\psi$ while land is acquired at land rent $\Omega$. From the first order condition $K / L=\alpha /(1-\alpha) \Omega$ (the price of capital is the numeraire) and the non-profit condition $\psi H=K+\Omega L$, it is immediate that $\log (\psi)=$ $(1-\alpha) \log (\Omega)+c$, where $c$ is a constant that cancels out in first-differences, i.e., $\Delta \ln (\psi)=$ $(1-\alpha) \Delta \ln (\Omega)$.

It is, therefore, possible to translate a land price capitalization effect, expressed in natural log terms, into a floor space price capitalization effect, also expressed in natural log terms, by multiplying the former by a land share parameter, which we set to 0.25 , following Ahlfeldt, Redding, et al. (2015) and Combes et al. (2013). 


\section{Empirical Results}

\subsection{Difference-in-differences}

Before we present the results of our DD analysis, we briefly note that the weights generated by the algorithm described in section 3.1 for the PTW DD do not exhibit an evident spatial pattern. Inevitably, every identification that is based on a weighted analysis gives a local average treatment estimate. In our case, however, it is at least not obvious that the PTW DD effects are identified from parcels with very particular characteristics that would impede generalizability within our sample. The spatial distribution of parcel weights along with a brief discussion is presented in the appendix (section 2).

In Figure 3, we illustrate the time-varying treatment effects, estimated according to the baseline DD model (1) and using the treatment function (2). We compare OLS (left) to the PTW (right) estimates and report rail noise and station distance effects, estimated unconditional (solid lines) and conditional (dotted lines) on each other. Estimated station distance effects are multiplied by 1 to ensure that positive numbers mean positive effects.

The OLS results turn out to be somewhat difficult to interpret. According to our estimates, parcels located closer to to-be-opened stations experienced significantly lower land price growth, which points to a violation of the common trend assumption. As shown, the trend is flat from 1890 to 1896 and positive afterwards. To infer the effect of the rail line, a judgement has to be made on a baseline period that provides a counterfactual trend. Because the relative trends are flat, it may be tempting to choose the 1890 to 1896 trend as a baseline, implying a price effect of a $1 \mathrm{~km}$ change in station distance of about 0.2 ln points over the subsequent 20 years. However, given that the concession for the line was granted in 1895, it is possible that the change in trend between 18811890 and $1890-1896$ is attributable to the rail line, in which case the rail effect would be considerably larger. Another, not particularly conclusive feature of the estimated OLS station effects is the insensitivity of the point estimates to controlling for rail noise effects.

The estimated OLS rail noise effects, plotted in the bottom-left graph of Figure 3, are even less conclusive. Not controlling for station distance effects, parcels which later become exposed to rail noise experience a relative decline in prices up until 1896, when, shortly after the concession was granted, the trend reverses. Controlling for station distance effects, the land price trends do not seem to depend on the degree to which parcels become exposed to rail noise. This pattern is not 
in line with rail noise being a disamenity. If anything, the unconditional OLS estimates suggest that rail noise is an amenity.

The PTW DD estimates are much more straightforward to interpret. In particular, it is reassuring to note that our PTW estimation approach achieves its purpose of eliminating pre-trends, i.e., there is no significant correlation between the 1881-1890 land price trend on the one hand and proximity to stations or exposure to rail noise on the other. Proximity and noise effects are also insignificant in 1896 and 1900 (years that have not been used in the construction of the weights), indicating that the common trends assumption holds within the weighted sample.

Station distance effects remain insignificant during all years prior to the opening of the line and become significantly positive afterwards, with a tendency to increase over time. The absence of anticipation effects in combination with the gradual adjustment after the opening of the line are consistent with an interpretation that the line represents a novel mode of transportation whose benefits were yet to be experienced. In quantitative terms, the estimated PTW station distance effects are within the range, though somewhat larger, than the corresponding effects obtained from OLS estimation, using the 1890-1896 period as a baseline. Controlling for rail noise, a $1 \mathrm{~km}$ decrease in distance to the station increases land prices in the long-run by some notable $0.3 \log$ points (35\%).

The estimated PTW rail noise effects also display an intuitive pattern. Controlling for station distance effects, a $10 \mathrm{db}$ increase in rail noise is associated with a reduction in land prices by about $5 \%$ in the long-run. In contrast to our results for station distance effects, we find notable anticipation effects of rail noise for 1896. This finding is plausible in light of the intense public debate about the disamenities of elevated rail lines. Opposition to elevated rail lines, after all, was large enough to prevent an elevated rail line being built along one of the most representative boulevards of the city (Friedrichstrasse) and to enforce an underground line within the boundaries of the city of Charlottenburg.

Separating the net effect of the transportation infrastructure into amenity and disamenity effects is at the heart of this paper. The effect of controlling for noise effects when estimating station distance effects and vice versa is clearly identifiable from the PTW estimates. In keeping with intuition, station distance effects increase by about one third if rail noise effects are controlled for. The effect of controlling for station distance effects on rail noise effects is even larger, in particular for the later years when station effects are significant. 


\section{Fig. 3. Difference-in-differences: Time-varying treatment effects}
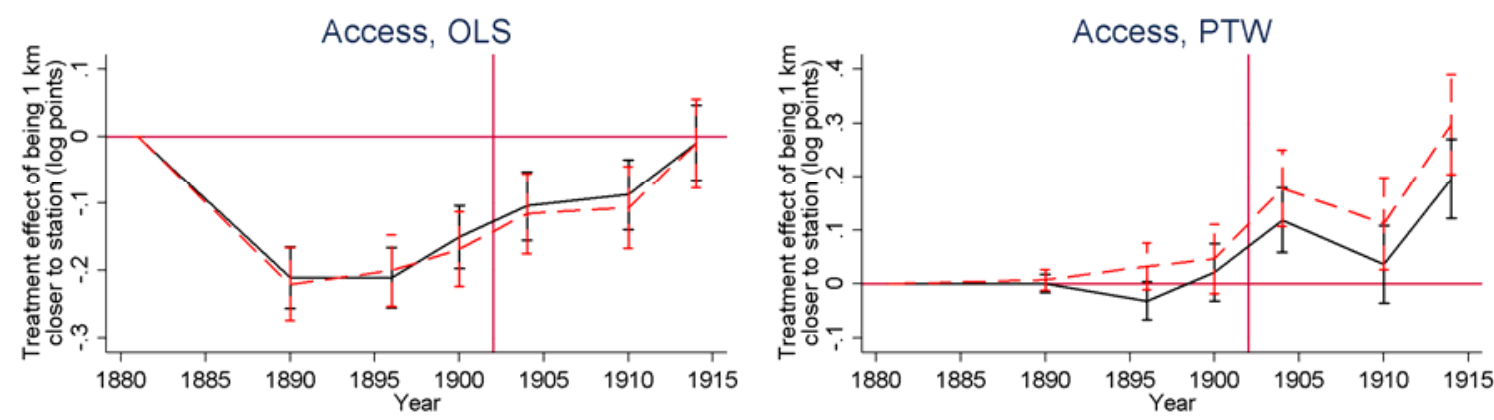

Unconditional on noise $\quad----$ Conditional on noise
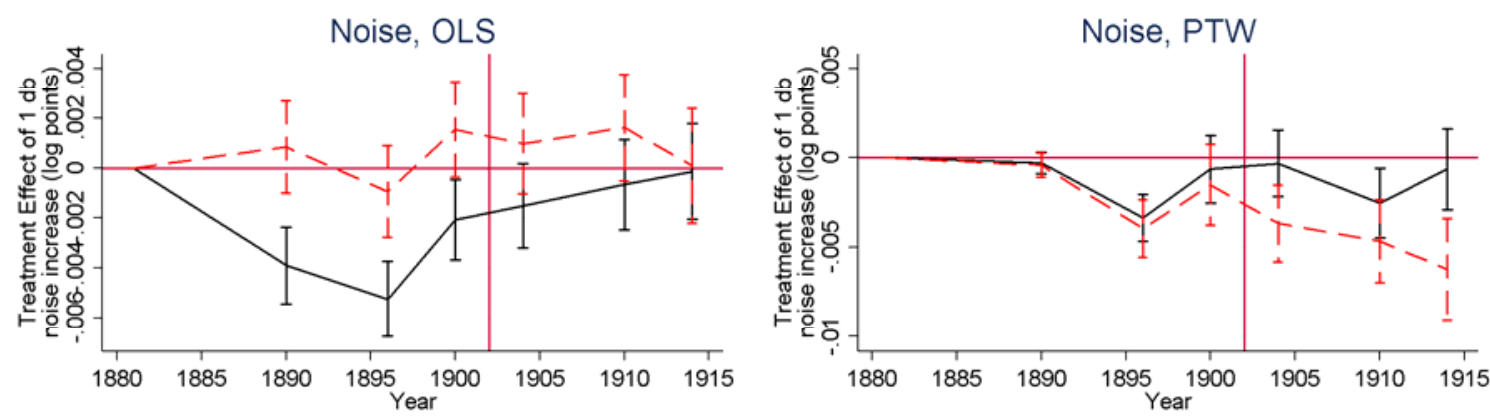

Unconditional on access

---- Conditional on access

Note: Time-varying treatment effects $\left(\alpha_{z}^{S}\right.$ and $\alpha_{z}^{N}$ ) based on baseline DD equation (1) and treatment function (2). Pre-trend weighted (PTW) models use weights constructed to minimize the conditional correlations between noise and the 1881-1890 land price trend as well as access (distance from station) and the 18811890 land price trend. Access parameters (effects of distance from station) multiplied by -1 so that positive shifts indicate positive economic effects. Vertical error bars indicate the $95 \%$ confidence interval based on standard errors that are clustered on parcels. Solid vertical lines denote the year of opening of the metro line (1902).

Informed by Figure 3, we now proceed to estimating parametric before-after DD effects, using our baseline specification (1) and the treatment function (3). Especially the rail noise PTW estimates suggest some anticipation effects in 1896. We, therefore, control for anticipation effects in 1896 and 1900, a choice that is also in line with the concession for the line being granted in 1895. In columns (1-4) of Table 1, we present PTW DD estimates of station distance effects not controlling for rail noise effects (1-2) and rail noise effects not controlling for station distance effects (3-4). In columns (5-6) of the table, we then report our station distance and rail noise effects estimated conditional on each other.

When we do not control for rail noise effects, our estimation results indicate that the price of a parcel located right at a station increases by $12.5 \%(=\exp (0.117)-1)$ after the opening of the line, compared to a parcel one kilometer away from a station. Analogously, rail noise effects are very 
close to zero and statistically insignificant if station accessibility is ignored. Controlling for anticipation effects in either case has a minor impact on the estimated rail effects. A comparison of these results to columns (5-6) highlights the importance of separately identifying rail amenity and disamenity effects. As shown in column (6), the station distance effect increases to $21 \%$ in our preferred model. Moreover, in line with Figure 3, the (negative) rail noise effect is now statistically significant. The point estimates indicate that a one decibel increase in rail noise causes a relative decline in land prices by $0.5 \%$. Comparing our estimates across the different specifications, the bias that results from ignoring countervailing (dis)amenity effects amounts to as much as about 40\% ([0.192 - 0.117]/0.192) in station distance effects and about 80\% in rail noise effects.

The treatment effects reported in Table 1 are derived from a comparison of the mean land price at the parcel level in the periods 1881-1890 and 1905-1914. Since this model ignores price trends after the opening of the line, the effects are smaller than the 1914 treatment effects reported in Figure 3. These parametric estimates, however, are closer to the standard approach in the literature, therefore providing a more reasonable starting point for a comparison of our quantitative results to contemporary estimates.

Tab. 1. PTW difference-in-differences estimates: Before-after comparison

\begin{tabular}{lllllll}
\hline & $(1)$ & $(2)$ & $\begin{array}{c}(3) \\
\text { Ln land price }(1881-1914)\end{array}$ & $(5)$ \\
\hline $\begin{array}{c}\text { Distance x after } \\
\left(S_{i} \times(t>1902)_{t}\right)\end{array}$ & $-0.119^{* * *}$ & $-0.117^{* * *}$ & & & $-0.175^{* * *}$ & $-0.192^{* * *}$ \\
Noise $\mathrm{x}$ after & $(0.025)$ & $(0.032)$ & & & $(0.030)$ & $(0.039)$ \\
$\quad\left(N_{i} \times(t>1902)_{t}\right)$ & & & -0.000 & -0.001 & $-0.003^{* * *}$ & $-0.005^{* * *}$ \\
\hline Parcel effects & Yes & Yes & Yes & Yes & Yes & Yes \\
Year effects & Yes & Yes & Yes & Yes & Yes & Yes \\
Anticipation effects & - & Yes & - & Yes & - & Yes \\
\hline $\mathrm{N}$ & 37,933 & 37,933 & 37,933 & 37,933 & 37,933 & 37,933 \\
$\mathrm{r} 2$ & 0.930 & 0.930 & 0.930 & 0.930 & 0.930 & 0.931 \\
\hline
\end{tabular}

Notes: Pre-trend weighted (PTW) models use weights constructed to minimize the conditional correlations between noise and the 1881-1890 land price trend as well as access (distance from station) and the 18811890 land price trend. After is a dummy variable indicating years after the line opening (1902). Announcement effects are distance and noise variables interacted with 1896 and 1900 effects. Balanced panel of repeated parcel observations for 1881, 1890, 1896, 1900, 1904, 1910, 1914. Standard errors in parentheses are clustered on parcels. ${ }^{*} p<0.10,{ }^{* *} p<0.05,{ }^{* * *} p<0.01$.

In Figure 4, we explore the countervailing nature of rail externalities from a different angle. To illustrate the net benefit from locating close to the elevated rail line, we plot the predicted joint station access and rail noise effect $\left(\hat{\alpha}^{S} S_{i}+\hat{\alpha}^{N} N_{i}\right)$ from model (6) in Table 1 against the straightline distance from the elevated track. The figure illustrates that, for the vast majority of parcels, being located closer to the elevated line is associated with net benefits relative to locations at the outer margin of our study area. Beyond $100 \mathrm{~m}$, the rail effect tends to be positive as reflected by 
the expected negative relationship between rail effect and track distance. At shorter distances, the net-proximity effect tends to be negative, reflecting an increasing noise disamenity. This inverse U-shaped relationship is the expected pattern for a densely developed area where noise tends to be highly localized. Some further interesting features of the countervailing nature of rail externalities are evident from Figure 3. As long as a location is sufficiently close to a station, the net effect of the line is positive, suggesting that the benefits from access to the line are relatively large. Land prices of parcels within $100 \mathrm{~m}$ of a station increase by at least $5 \%$ relative to those located at the margin of our study area. For parcels within a 100-200m distance to a station, the effect is about half the size. Among the parcels further away from the nearest station, there are at least a handful for which the negative rail noise effect exceeds the positive station access effect.

As a plausibility check, we illustrate this negative net effect with a numerical example. The largest distance between two stations along the elevated line is about $1 \mathrm{~km}$, implying that a parcel can be located at most $500 \mathrm{~m}$ from a station while still being located directly at the track. At $500 \mathrm{~m}$, the benefit from rail access compared to the outer margin of the study area amounts to some $(0.5 \times 1.92=) 0.096 \log$ points. At this location, a parcel will be exposed to a very high noise level. Multiplying the $99^{\text {th }}$ percentile in the distribution of rail noise of $24 \mathrm{db}$ by the per-decibel noise effect of $(-0.005)$ yields an effect of -0.12 log points, which indeed more than compensates for the accessibility effect. 


\section{Fig. 4. Net benefit of proximity to rail line}

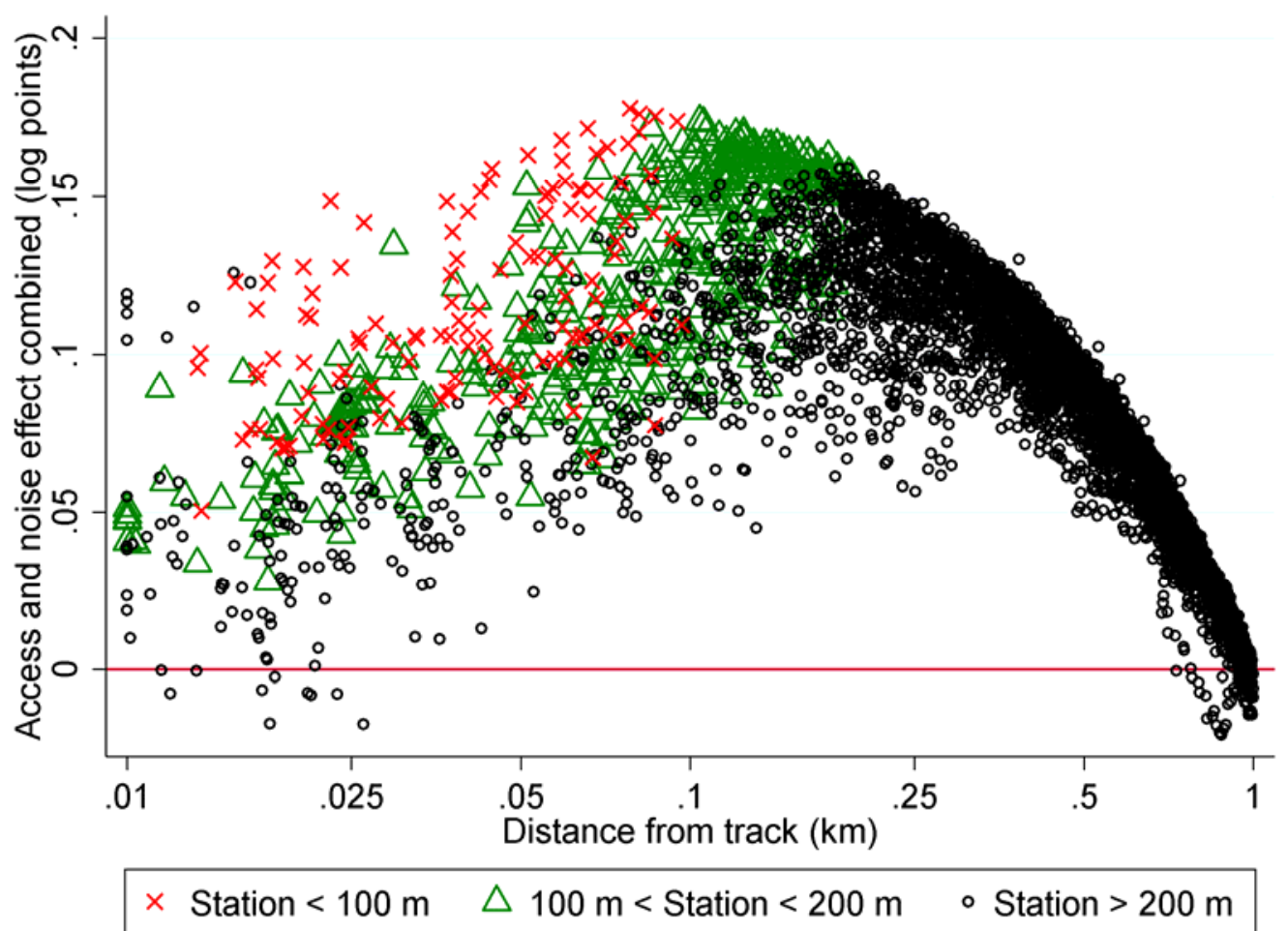

Notes: Figure illustrates the joint effects of station distance and rail noise predicted by model (6) in Table (1), formally: $\hat{\alpha}^{S} S_{i}+\hat{\alpha}^{N} N_{i}$. All effects are expressed relative outer margin of our study area. Therefore, we do a normalization by the mean across the predicted effects within the outmost 50 meters. Station indicates distance from the nearest station.

In Table 2, we provide a number of robustness checks on our preferred empirical model, reported in column (6) of Table 1. We begin by estimating the full version of specification (1), allowing for time-varying implicit prices for various characteristics throughout columns (1-5). The interaction between time-invariant covariates and year effects are demanding controls, creating concerns of over-controlling. Some changes in implicit prices, e.g., distance from CBD or distance from the Kurfürstendamm, could be caused by the elevated line, implying a potential bad control problem (Angrist \& Pischke, 2009). Yet, the station distance effect remains significant throughout all models, although it is reduced considerably. The noise effect becomes insignificant once we allow for time-varying effects for distance from rivers, lakes, or canals. Since the elevated track was partially built along a canal, however, it is difficult to separately identify the time-invariant effect of time-varying noise and the time-varying effect of time-invariant distance from rivers, lakes, or canals. 
Tab. 2. PTW difference-in-differences estimates: Robustness

\begin{tabular}{|c|c|c|c|c|c|c|}
\hline & (1) & $(2)$ & $\begin{array}{c}(3) \\
\text { Ln land price }\end{array}$ & $\begin{array}{l}(4) \\
(1881-1914\end{array}$ & $(5)$ & (6) \\
\hline $\begin{array}{l}\text { Distance } \times \text { after }\left(S_{i} \times\right. \\
\quad(t>1902) t\end{array}$ & $\begin{array}{l}-0.132^{* * *} \\
(0.040)\end{array}$ & $\begin{array}{l}-0.099^{*} \\
(0.039)\end{array}$ & $\begin{array}{l}-0.130^{* * *} \\
(0.032)\end{array}$ & $\begin{array}{l}-0.113^{* * *} \\
(0.033)\end{array}$ & $\begin{array}{l}-0.071^{*} \\
(0.032)\end{array}$ & $\begin{array}{l}-0.105^{* *} \\
(0.040)\end{array}$ \\
\hline Noise $\times$ after $\left(N_{i} \times(t>1902)_{t}\right)$ & $\begin{array}{l}-0.004^{* * *} \\
(0.001)\end{array}$ & $\begin{array}{l}-0.004^{* * *} \\
(0.001)\end{array}$ & $\begin{array}{l}0.001 \\
(0.001)\end{array}$ & $\begin{array}{l}-0.001 \\
(0.001)\end{array}$ & $\begin{array}{l}-0.001 \\
(0.001)\end{array}$ & $\begin{array}{l}-0.002 \\
(0.001)\end{array}$ \\
\hline Distance $\times($ year -1902$)$ & & & & & & $\begin{array}{l}-0.001 \\
(0.001)\end{array}$ \\
\hline $\begin{array}{l}\text { Distance } \times(\text { year }-1902) \mathrm{x} \\
\quad(t>1902)\end{array}$ & & & & & & $\begin{array}{l}-0.009^{* *} \\
(0.003)\end{array}$ \\
\hline Noise $\times($ year -1902$)$ & & & & & & $\begin{array}{l}-0.000 \\
(0.000)\end{array}$ \\
\hline $\begin{array}{l}\text { Noise } \times(\text { year }-1902) \times \\
\quad(t>1902)\end{array}$ & & & & & & $\begin{array}{l}-0.000 \\
(0.000)\end{array}$ \\
\hline Parcel effects & Yes & Yes & Yes & Yes & Yes & Yes \\
\hline Year effects & Yes & Yes & Yes & Yes & Yes & Yes \\
\hline Anticipation effects & Yes & Yes & Yes & Yes & Yes & Yes \\
\hline Distance from CBD effects & Yes & Yes & Yes & Yes & Yes & - \\
\hline Distance from Kudamm effects & - & Yes & Yes & Yes & Yes & - \\
\hline Distance from water body effects & - & - & Yes & Yes & Yes & - \\
\hline Distance from main street effects & - & - & - & Yes & Yes & - \\
\hline Tram density effects & - & - & - & - & Yes & - \\
\hline $\mathrm{N}$ & 37,933 & 37,933 & 37,933 & 37,933 & 37,933 & 37,933 \\
\hline $\mathrm{r} 2$ & 0.934 & 0.936 & 0.942 & 0.944 & 0.944 & 0.931 \\
\hline
\end{tabular}

Notes: Pre-trend weighted (PTW) models use weights constructed to minimize the conditional correlations between rail noise and the 1881-1890 land price trend as well as station distance and the 1881-1890 land price trend. After is a dummy variable indicating years after the line opening (1902). Announcement effects are distance and noise variables interacted with 1896 and 1900 effects. All other effects are time-invariant covariates interacted with year effects. Distance from CBD is defined as distance from the underground station "Stadtmitte" (downtown). Distance from Kudamm (slang for Kurfürstendamm) is defined as distance from Breitscheidplatz. Tram density is defined as kernel smoothed density of tram tracks within $2 \mathrm{~km}$ (bandwidth according to Silverman (1986)). Data is a balanced panel of repeated parcel observations for $1881,1890,1896,1900,1904,1910,1914$. Standard errors in parentheses are clustered on parcels. ${ }^{*} p<$ $0.05,{ }^{* *} p<0.01,{ }^{* * *} p<0.001$.

In column (6), we add interaction terms between our treatment measures and time trends (year 1902 ) and the same interacted with an after-period dummy $(t>1902)$. With this specification, we test for an effect of the treatments on levels and trends in land prices. The near to zero and insignificant pre-trend effects [Distance $\times($ year -1902$)$ and Noise $\times(y e a r-1902)]$, once again, confirm that the PTW achieves its purpose of eliminating the conditional correlations between pre-intervention price trends on the one hand and rail noise and station access on the other. The estimated station distance effect on land price levels $\left(S_{i} \times(t>1902)_{t}\right)$ about halves in magnitude compared to the benchmark specification (column 6 of Table 1), but remains significant. The post-intervention trend in the distance treatment effect [ Distance x (year - 1902) x after], however, reveals that 10 years after the opening of the line the treatment effect has increased to some $-10.5-10 \times 0.009=-0.195 \log$ points, which is remarkably close to the baseline effect reported in column (6) of Table 1. The post-intervention noise level [Noise $\times$ (year -1902)] and trend [Noise $\times($ year -1902$) \times(t>1902)]$ effects are both negative as expected, though not individu- 
ally significant. The cumulated effect of -0.004 after ten years, however, is not only close to the baseline estimate, but also statistically significant at the $1 \%$ level. ${ }^{9}$

\subsection{Regression discontinuity}

The tunnel entrance between the stations Nollendorfplatz and Wittenbergplatz, where the elevated line turns into an underground line, provides a source of discrete variation in rail disamenities. In Figure 5, we compare how growth rates in land prices from 1900 to 1904 (the line opened in 1902) differ between the areas along the underground (negative distance values) and elevated (positive distance values) sections of the line. We restrict the sample to plots within close proximity to the line, because this is where the noise disamenity of an elevated line is concentrated in a densely developed urban setting (see Figure 2 for an illustration).

The key feature of interest in Figure 5 is the notable difference in land price growth between the underground and the elevated sections of the line. Approaching the tunnel entrance from the west (negative distances), growth rates drop by about $0.1 \mathrm{log}$ points as one enters the impact area of the elevated area. This pattern is, as expected, in line with a highly localized noise disamenity.

9 The standard error is computed as follows : $\exp \left(\operatorname{var}\left(\widehat{\alpha^{N}}\right)+10^{2} \times \operatorname{var}\left(\widehat{\alpha^{N T}}\right)+2 \times(10) \times \operatorname{cov}\left(\widehat{\alpha_{A}^{N}}, \widehat{\alpha_{A}^{N T}}\right)\right)-1$, where $\widehat{\alpha^{N}}$ is the estimated noise treatment level effect (as defined in equation (3) and $\widehat{\alpha}^{\mathbb{N T}}$ is estimated trend effect [Noise $\times$ (year -1902 ) $\times(t>1902)]$. 


\section{Fig. 5. Discontinuity in land price growth from 1900 to 1904}

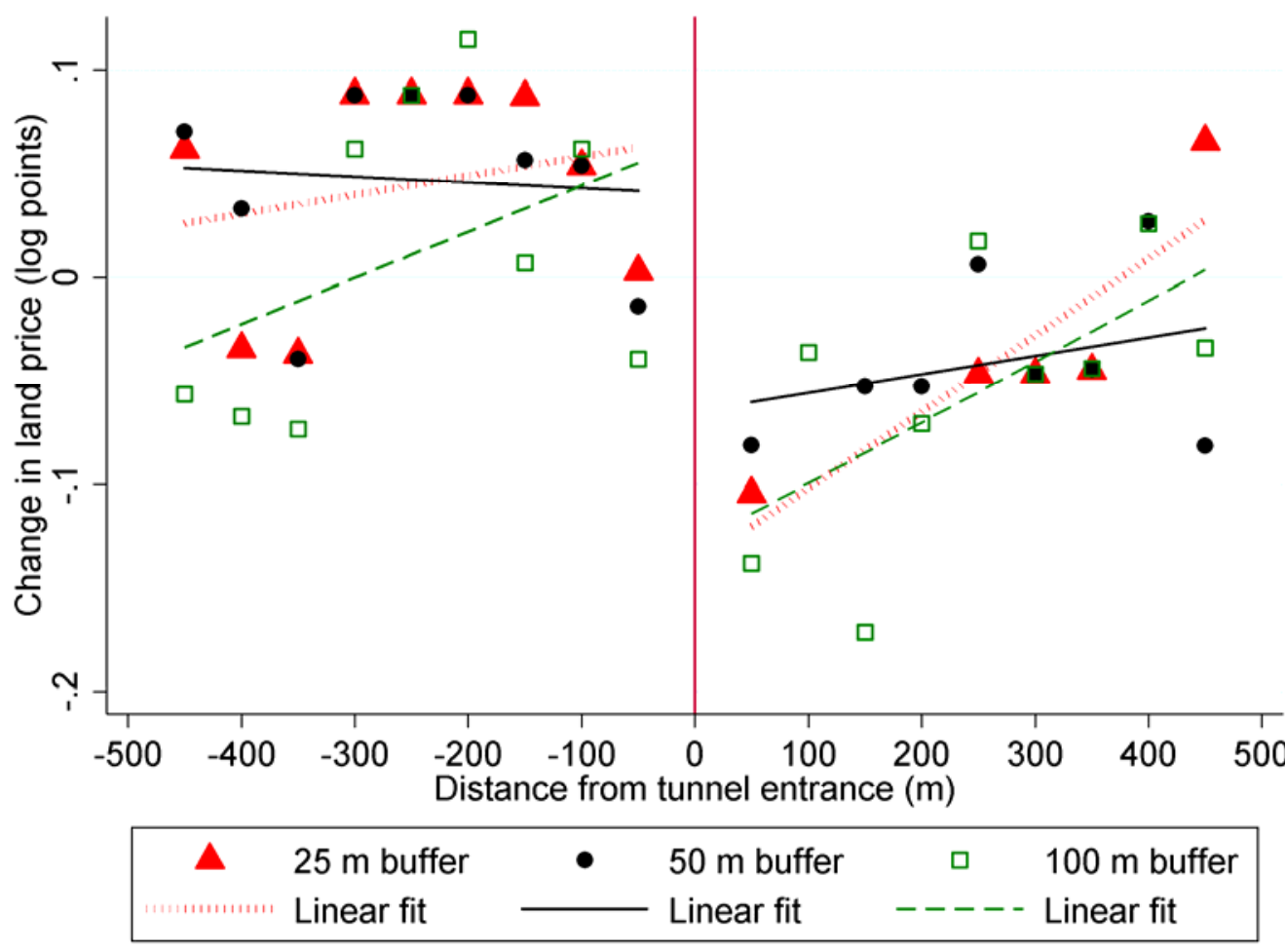

Notes: Each icon illustrates the mean of change in log land price from 1900 to 1904 within a grid cell. One dimension of the grid cells are $50 \mathrm{~m}$ bins defined based on the distance from the orthogonal line intersecting with the track at the tunnel entrance (the dotted line in Figure 2). The other dimension is a distance buffer defined around the track with the width defined in the legend. Negative distances from the tunnel refer to the underground section.

In Table 3, we provide parametric estimates of this discontinuity, based on the RDD-DD specification (6). We begin with a simplified version in column (1), where we compare 1900-1904 land price growth rates across all parcels within the underground section and the elevated section of the line. On average, growth rates were about $4 \%$ lower within the elevated section (i.e., the section with noise exposure). In columns (2) and (3), we narrow down the sample to parcels in proximity to the track and the tunnel entrance. For these more restrictive samples, the growth differential increases to about 9.4\%, which confirms the illustrative results from Figure 5 and indicates a significant rail noise disamenity.

Next, we allow for separate trends in the running variable on both sides of the tunnel entrance to capture locational characteristics that change smoothly in space. We experiment with linear (column 4) and quadratic (column 5) trends. Finally, we estimate the full model (equation 6) controlling for a range of location characteristics, including the distance from the nearest metro rail station, the distance from the nearest mainline rail station, the distance from the nearest water body, whether parcel is in commercial use, the density of tram stations as well as the change in this den- 
sity. The differential in land price growth further increases up to $11.3 \%$ in column (6). Moreover, the estimated coefficient remains statistically significant at conventional levels, even though we consider this specification to be relatively demanding, given the limited number of observations. In the appendix (section 3), we provide a sensitivity analysis, using various combinations of track buffer widths, entrance buffer widths and polynomial orders of trends. The mean and median estimates are within the range of the preferred estimates (3-6) in Table 3.

Tab. 3. Discontinuity estimates I

\begin{tabular}{lllllll}
\hline & $(1)$ & $(2)$ & $(3)$ & $(4)$ & $(5)$ & $(6)$ \\
\cline { 2 - 7 } & \multicolumn{7}{c}{ Ln land price 1904 - log land price 1900 } \\
\hline Elevated track (Distance & $-0.040^{* * *}$ & $-0.067^{* * *}$ & $-0.090^{* * *}$ & $-0.093^{*}$ & $-0.104^{*}$ & $-0.107^{*}$ \\
from tunnel $>0)$ & $(0.004)$ & $(0.012)$ & $(0.024)$ & $(0.048)$ & $(0.054)$ & $(0.062)$ \\
\hline Track buffer (m) & $\infty$ & 50 & 50 & 50 & 50 & 50 \\
Tunnel buffer (m) & $\infty$ & $\infty$ & 500 & 500 & 500 & 500 \\
Linear trends & - & - & - & Yes & - & - \\
Quadratic trends & - & - & - & - & Yes & Yes \\
Controls & - & - & - & - & - & Yes \\
\hline Observations & 11,354 & 710 & 84 & 84 & 84 & 84 \\
R2 & 0.011 & 0.044 & 0.157 & 0.174 & 0.260 & 0.288 \\
\hline
\end{tabular}

Notes: Track buffer defines the sample of parcels included in terms of distance from the track. Tunnel buffer defines the sample of parcels included in terms of distance to the orthogonal intersecting with the track at the tunnel entrance (the black dotted line in Figure 5). Linear trends are distance from the orthogonal and distance from the orthogonal interacted with being on the elevated section of the track. Quadratic trends are the same and same variables squared. Controls include distance from the nearest metro station, distance from the nearest mainline station, distance from the nearest water body, dummy for parcels with commercial use, kernel density of tram stations, change in in kernel tram station density. Tram density is defined as kernel smoothed density of tram tracks within $2 \mathrm{~km}$ (bandwidth according to Silverman (1986)). Robust standard errors in parentheses. ${ }^{*} p<0.10,{ }^{* *} p<0.05,{ }^{* * *} p<0.01$.

In columns (1-4) of Table 4, we conduct a similar analysis, but now use land price growth during periods before and after the intervention as dependent variables. As shown, we find only small and insignificant effects for all periods, suggesting that the noise disamenity effect around the tunnel entrance capitalized into land prices within a relatively short period of time. Also, the absence of similar effects in the other periods makes it unlikely that the effects reported in Table 3 are driven by unobserved trends that are correlated with, but unrelated to, the noise disamenity. In this context, we note that we have used model (3) from Table 3 as the baseline model because the point estimate is relatively close to the more demanding specifications, but the standard errors are significantly smaller. This imposes a harder hurdle for a falsification test, making the statistical insignificance of the estimates reported in Table 4, columns (1-4) more meaningful.

In the remaining columns of Table 4, we address the question of whether the arguably wellidentified RDD-DD estimates reported above are in line with the PTW DD estimates reported in the previous section. In column (5), we use the $1904 \mathrm{db}$ rail noise as a dependent variable. Note 
that because there was no rail noise in 1900, the variable effectively corresponds to the change in noise from 1900 to 1904 . On average, areas within $50 \mathrm{~m}$ of the elevated line were exposed to a $15.1 \mathrm{db}$ noise pressure. Dividing the land price effect from Table 3, column (3) by this increase in rail noise results in a per decibel effect of $0.6 \%$, which is remarkably close to our preferred PTW DD estimate of $0.5 \%$ (Table 1, column 6). In column (6), we present an alternative 2SLS approach, arriving at virtually the same estimate. Essentially, we provide a first-difference estimate of the effect of noise on land price, restricting the identifying variation to the discontinuity arising at the tunnel entrance. We argue that the fact that the estimated RDD-DD noise effects are so closely aligned with the PTW DD lends some credibility to the latter approach.

Tab. 4. Discontinuity estimates II - Placebo tests and 2SLS noise effects

\begin{tabular}{|c|c|c|c|c|c|c|}
\hline & (1) & (2) & (3) & (4) & (5) & (6) \\
\hline & $\begin{array}{l}\text { Ln land } \\
\text { price } \\
1896 \text { - log } \\
\text { land price } \\
1890\end{array}$ & $\begin{array}{l}\text { Ln land } \\
\text { price } \\
1900 \text { - log } \\
\text { land price } \\
1896\end{array}$ & $\begin{array}{l}\text { Ln land } \\
\text { price } \\
1910 \text { - log } \\
\text { land price } \\
1904\end{array}$ & $\begin{array}{l}\text { Ln land } \\
\text { price } \\
1914 \text { - log } \\
\text { land price } \\
1910\end{array}$ & $\begin{array}{l}\text { Noise } \\
1904(\mathrm{db})\end{array}$ & $\begin{array}{l}\text { Ln land } \\
\text { price } \\
1904 \text { - log } \\
\text { land price } \\
1900\end{array}$ \\
\hline & OLS & OLS & OLS & OLS & OLS & 2 SLS \\
\hline $\begin{array}{l}\text { Elevated track (Dis- } \\
\text { tance from tunnel }>0) \\
\text { Noise } 1904(\mathrm{db})\end{array}$ & $\begin{array}{l}-0.018 \\
(0.012)\end{array}$ & $\begin{array}{l}-0.022 \\
(0.024)\end{array}$ & $\begin{array}{l}-0.010 \\
(0.054)\end{array}$ & $\begin{array}{l}-0.002 \\
(0.066)\end{array}$ & $\begin{array}{l}15.119^{* * *} \\
(1.640)\end{array}$ & $\begin{array}{l}-0.006^{* * *} \\
(0.002)\end{array}$ \\
\hline Track buffer (m) & 50 & 50 & 50 & 50 & 50 & 50 \\
\hline Tunnel buffer (m) & 500 & 500 & 500 & 500 & 500 & 500 \\
\hline Observations & 84 & 84 & 84 & 84 & 84 & 84 \\
\hline$R^{2}$ & 0.020 & 0.008 & 0.001 & 0.000 & 0.488 & 0.092 \\
\hline
\end{tabular}

Notes: Instrument in (6) is Elevated track (Distance from tunnel $>0$ ). Robust. Noise $(\mathrm{db})$ is noise emanated by the U-Bahn in 1904 (U-Bahn noise in 1900 is 0). Track buffer defines the sample of parcels included in terms of distance from the track. Tunnel buffer defines the sample of parcels included in terms of distance to the orthogonal intersecting with the track at the tunnel entrance (the black dotted line in Figure 2). Standard errors in parentheses. ${ }^{*} p<0.10,{ }^{* *} p<0.05,{ }^{* * *} p<0.01$.

\subsection{Comparison to contemporary estimates}

The station distance and rail noise effects discussed above are expressed in terms of a percentage effect on land prices. The majority of existing estimates of rail effects, in contrast, are based on property transaction prices, which are typically more readily available. As discussed in Section 3.3, it is possible, under some reasonably plausible assumptions, to convert percentage land price effects into percentage house price effects by using a multiplicative factor of 0.25 .

Applying this conversion, our estimates imply that a reduction in distance from the nearest metro rail station - holding rail disamenities constant - increases property prices by $5.3 \%$. To put this number into context, it is useful to consider the results by Gibbons and Maching (2005), who provide one of the most careful difference-in-differences analyses of rail effects to date. Using the 
1997 extension of the London Underground and Dockland Light Railway network as source of variation, they find that property prices increase by $1.5 \%$ to $5.5 \%$ for a one-kilometre reduction in station distance. Another recent difference-in-differences estimate of rail effects is provided by Dubé et al. (2013) who analyse the effects of a commuter rail line in Montreal, Canada. They estimate a property price effect of station opening of $9.7 \%$ within a $0-500 \mathrm{~m}$ radius and of $2.7 \%$ within a 1000-1500 m radius. From these estimates, a per km station distance effect of $7 \%$ can be inferred. Debrezion et al. (2007) report, based on a meta-analysis of 57 studies, that property prices increase by $2.4 \%$ for every 250 meter reduction in station distance, which corresponds to a per kilometre effect of $9.2 \%$. The review, however, is primarily based on cross-sectional studies, which tend to exaggerate station distance effects by several percentage points (Gibbons \& Machin, 2005).

Applying a similar transformation, our baseline estimate of the per decibel noise effect on land prices of $0.5 \%$ (Table 1, column 6) translates into a $0.125 \%$ per decibel effect on property prices. While there is empirical evidence that rail lines can have negative net effects on nearby property prices (Harrison \& Rubinfeld, 1978; Leggett \& Bockstael, 2000; J. P. Nelson, 1978), the literature, to the best of our knowledge, does not offer well-identified estimates of rail noise capitalization effects that directly compare to ours. Exploiting an unexpected change in flight regulation, Boes and Nüesch (2011) provide a difference-in-differences estimate of the effect of aircraft noise on apartment prices of $0.5 \%$ per decibel. This is close to the $0.6 \%$ effect that emerges from a metaanalysis of the larger cross-sectional hedonic literature on aircraft noise capitalization effects (J. P. Nelson, 2004).

We augment our discussion of findings from the literature by comparing our historic estimates to contemporary rail effects directly. Given the absence of major intra-urban rail projects in Berlin during the past decades, we provide a conventional cross-sectional hedonic analysis, regressing property transaction prices (making use of the same data set as in Ahlfeldt and Maennig (2015)) on contemporary measures of rail noise and station distance. We are able to improve the identification of rail noise effects by restricting the identifying variation to the discontinuous change in noise that arises at nine tunnel entrances where elevated lines turn into underground lines and vice versa. We highlight that unlike in many hedonic property price analyses our data allows using the natural log of transaction price normalized by the lot size as a dependent variable. Under the assumptions made in Section 3.3 in the main paper, this dependent variable is a linear transformation of the land price (Epple, Gordon, \& Sieg, 2010). Therefore, the estimated station distance 
and noise effects are directly comparable to the historic estimates using the natural log of land prices as dependent variable. ${ }^{10} \mathrm{~A}$ formal description of the model is in the appendix (Section 4 ).

Our analysis includes the entire post-unification commuter (S-Bahn) and underground (U-Bahn) network in Berlin, which consists of $475 \mathrm{~km}$ rail and 275 stations. Table 5 reports the results. In columns (1) to (3) we provide a hedonic analysis in which we control for a range of structural and locational characteristics, control for arbitrary shocks to station catchment areas (2) and restrict the analysis to areas nearby stations (3) to improve identification. In columns (4) to (6) the noise effects are identified from an RDD model similar to the one reported in Table 4, column (6). We use a dummy variable indicating transactions along elevated sections of the network as an instrument for noise. At the same time, we control for arbitrary shocks to each of the nine network corridors where a tunnel entrance is located. A corridor is defined as a 100-meter-wide buffer around a network segment reaching 1000 meters in both directions from an entrance. We also add corridor-specific running variables, which are defined as distance from the entrance, where observations within the tunnel section receive negative values. Our preferred RDD noise estimates are about twice as large as the conventional hedonic estimates and more than twice as large as our estimates derived from historic data. Applying the conversion factor discussed in Section 3.3 our estimates imply a per decibel house property price effect of about $0.4 \%$, which is significantly closer to contemporary estimates of aircraft noise effects. The estimated station distance effects are generally within the range of our historic estimates and the contemporary estimates in the litereature.

In sum, it seems fair to conclude that our historic estimates of station distance effects are similar in magnitude to contemporary effects, suggesting that the value of access and time to transportation has remained remarkably constant over the last century. In contrast, our evidence suggests that sensitivity to (rail) noise has increased substantially over time, presumably reflecting increasing preferences for environmental quality. The combination of relatively firm accessibility effects and noise effects that have increased over time also explains why, as discussed above, some previous studies have found negative net effects of proximity to rail lines whereas, in our historic setting, the net effect remains close to zero at least.

10 To see this, combine the first order condition and the non-profit condition discussed in Section 3.3 to get $\psi H / L=1 /(1-\alpha) \Omega$ or $\ln \psi(H / L)=\ln \Omega-\ln (1-\alpha)$. 
Tab. 5. Contemporary hedonic analysis of rail noise and station distance effects

\begin{tabular}{lllllll}
\hline & $(1)$ & $(2)$ & $(3)$ & $(4)$ & $(5)$ & $(6)$ \\
\cline { 2 - 7 } & $-0.172^{* * *}$ & $-0.154^{* * *}$ & $-0.251^{* * *}$ & $-0.155^{* * *}$ & $-0.113^{* * *}$ & $-0.239^{* * *}$ \\
\hline Distance $(\mathrm{km})$ & $(0.004)$ & $(0.009)$ & $(0.048)$ & $(0.004)$ & $(0.009)$ & $(0.050)$ \\
& $-0.010^{* * *}$ & $-0.006^{* * *}$ & $-0.006^{* * *}$ & $-0.019^{* * *}$ & $-0.015^{* * *}$ & $-0.014^{* * *}$ \\
Rail noise $(\mathrm{db})$ & $(0.000)$ & $(0.001)$ & $(0.001)$ & $(0.003)$ & $(0.004)$ & $(0.005)$ \\
& Yes & Yes & Yes & Yes & Yes & Yes \\
\hline Controls & Yes & - & - & Yes & - & - \\
Year effects & - & Yes & Yes & - & Yes & Yes \\
Station x year effects & - & - & - & Yes & Yes & Yes \\
Corridor x year effects & - & - & - & Yes & Yes & Yes \\
Corridor x running variable effects & - & & & Yes & Yes & Yes \\
\hline Noise instrument & All & All & Station & All & All & Station \\
\hline Sample & & & distance & & & distance \\
& & & $<0.5 \mathrm{~km}$ & & & $<.5 \mathrm{~km}$ \\
\hline $\mathrm{N}$ & 71,313 & 71,313 & 24,762 & 71,313 & 71,313 & 24,762 \\
$\mathrm{r} 2$ & 0.265 & 0.586 & 0.640 & 0.349 & 0.587 & 0.644 \\
\hline
\end{tabular}

Notes: Unit of analysis is property transaction. Controls include structure age, dummies for location within a block (corner lot, street front, backyard, etc.), dummies for building condition (poor, good), distance from nearest lake, river or canal, distance from nearest park or forest, distance from nearest landmark building, distance from nearest playground, distance from nearest main street, street noise (excluding rail noise). Station effects identify groups of property which have the same nearest rail station. Corridor effects identify groups of properties within 100-meter buffers along a rail line, spreading 1000 meter in both directions from a tunnel entrance. Standard errors in parentheses are robust in (1) and (4), clustered station x year effects in all other models. ${ }^{*} p<0.10,{ }^{* *} p<0.05,{ }^{* * *} p<0.01$.

\subsection{Fiscal case for underground metro lines}

Building an underground line is significantly more expensive than building an elevated line. Underground lines, in return, avoid sizable disamenities. From this trade-off, a number of questions arise: Can the extra costs for building an underground line be economically justified? To what extent should local landlords contribute to the (extra) costs? And how long does it take to refinance the extra costs via property tax revenues? To analyze these questions, we provide some simple back-of-the-envelope calculations for which we need an estimate of the extra cost of a hypothetical underground line as well as an estimate of the extra land value generated in this counterfactual.

Bousset (1935) reports the per kilometre construction costs for 31 segments of the Berlin metro rail network opened until 1930, including per km cost of about 2 million reichsmark (RM) for a five km long sub segment of the elevated part of Line A. Multiplying the per km cost by the total length of the elevated section of eight km yields construction costs of about 16 million RM. To approximate the extra cost associated with a hypothetical underground section, we run an auxiliary regression of the natural log of per km construction costs against a dummy indicating underground sections, controlling for track width and period (five years) effects. The results, reported in Section 5 in the appendix, indicate that building an underground section in the early $20^{\text {th }}$ cen- 
tury in Berlin was about three times as expensive as building an elevated section. Multiplying the estimated construction cost of the Line A by this factor yields a counterfactual construction cost of about 50 million and an extra cost for the underground line of about 34 million.

Using our baseline noise estimate (Table 1, column 6), it is relatively straightforward to approximate the aggregate effect of rail noise on the value of land. In this respect, it is worth emphasizing that our plots include all types of land uses; the aggregate land value effect, therefore, reflects both changes in utility and the productivity of land. We aggregate the plot-level land price observations to a $50 \times 50 \mathrm{~m}$ grid, which allows for rich spatial variation in rail noise and, at the same time, ensures that we cover the entire built-up area. For each grid cell, we multiply the percentage noise effect by the 1900 land price by the geographic size of the grid cell. The resulting land price effects by grid cell are illustrated in the appendix (Section 6). Summing over all grid cells, then, gives an estimate of the aggregate land value that would have been generated if an underground line were built. We assume that rail noise impacts only on the value of land, but not on the structure value.

In a further set of auxiliary regressions of the natural log of land price on location fixed effects and a year trend, we find that annual land price appreciation rates tended to fluctuate around $5 \%$ in Berlin from the late $19^{\text {th }}$ century to the early $21^{\text {st }}$ century, which is close to the mean interest rate across years in the same period. Moreover, there is a positive correlation between the two variables (see Section 7 in the appendix). We, thus, assume for simplicity that in the long-run land prices grow at a rate that equates to the opportunity cost of capital. For any property tax rate, it is then immediate to compute the number of years required to refinance the extra cost of the underground line by the extra property tax revenues generated by the higher land value.

In Table 6, we consider a range of noise capitalization effects from $0.15 \%$ (our historic baseline) to $0.3 \%$ (close to our contemporary estimate) and $0.6 \%$ (the literature consensus on aircraft noise effects). We also consider property tax rates ranging from $0.5 \%$ (Berlin) to $1.5 \%$ (United States) to reflect the variety of tax regimes around the world (see Section 8 in the appendix for a discussion). Based on our historic noise estimates, the aggregate land value increase in a counterfactual scenario with an underground line amounts to slightly more than one half of the extra cost of going underground (19.7 million RM). Consequently, the welfare case for an underground line would rest on strong assumptions regarding wider benefits of an underground line to other than local residents and firms (e.g., to visitors and tourists). In a low property tax environment, such as Germany, it could take up to 350 years to recover the costs via property taxes. It is, therefore, no 
surprise that the line was built as an elevated line and that it took major protests and political pressure to force the line underground within the boundaries of Charlottenburg.

The welfare case improves, however, when we consider contemporary estimates of noise capitalization effects of $0.3 \%$. Since the increase in land values more than offsets the extra costs of going underground, any additional non-local benefits would result in a strong positive welfare balance. While in theory landlords would be able to bear the extra cost for an underground line without making losses, such contributions are difficult to negotiate in practice, especially since fair contributions have to be determined based on the net effect of amenities and disamenities. The increase in the property tax base, however, allows for a less controversial refinancing of the costs in the long-run. Based on the contemporary noise estimate and a reasonable property tax rate of $1 \%$, property taxes would have refinanced the extra cost for an underground line within 88 years and, thus, within the past lifetime of Line A.

Tab. 6. The fiscal case for an underground line

\begin{tabular}{|c|c|c|c|c|c|}
\hline & $(1)$ & $(2)$ & $(3)$ & $(4)$ & $(5)$ \\
\hline Noise effect $(\text { per } \mathrm{db})^{\mathrm{a}}$ & $0.15 \%$ & $0.15 \%$ & $0.30 \%$ & $0.60 \%$ & $0.60 \%$ \\
\hline Property tax rate & $0.50 \%$ & $1 \%$ & $1 \%$ & $1 \%$ & $1.5 \%$ \\
\hline Estimated total cost (million $1900 \mathrm{RM})$ & \multicolumn{5}{|c|}{15.94} \\
\hline Estimated underground extra cost (million $1900 \mathrm{RM}$ ) & \multicolumn{5}{|c|}{34.36} \\
\hline Aggregated noise effect on land value (mil. 1900 RM) & 19.7 & 19.7 & 39.4 & 78.8 & 78.8 \\
\hline Yearly tax revenue (million $1900 \mathrm{RM}$ ) & 0.1 & 0.2 & 0.39 & 0.79 & 1.18 \\
\hline Year to recover underground extra costs & 344 & 172 & 88 & 43 & 29 \\
\hline
\end{tabular}

Notes: Cost estimates based on Bousset (1935). Estimated total cost result from multiplying the reported 1902 per $\mathrm{km}$ costs of over elevated sections by $8 \mathrm{~km}$ (the length of the elevated sections of the Line A). The estimated underground extra cost result multiplying the total cost by the percentage extra costs for underground segments obtained from an auxiliary regression reported in Section 5 of the appendix. Years to recover extra costs are calculated under the assumption that land values grow at a rate similar to cost of capital. a Expressed as house price effect.

It is noteworthy that the extra cost for the construction of underground lines appear to have declined over time. The current rule of thumb suggests that costs of an underground line are about twice the cost of an elevated line (Flyvbjerg, Bruzelius, \& van Wee, 2008). These lower extra costs would imply an even stronger welfare case and result in a break-even point within just about 40 years. These results rationalize the shift away from elevated lines towards underground lines that could be observed during the $20^{\text {th }}$ century.

\section{Conclusions}

In this paper, we separate the countervailing effects of elevated rail lines on the value of land. Our estimates enrich a literature that has focused primarily on the aggregate (or net) effect of rail. 
Using spatiotemporal variation from the first German electrified metro rail as a source of exogenous variation, we find that, ceteris paribus, a $1 \mathrm{~km}$ reduction in distance to the nearest station increases land prices (house prices) by $21.1 \%$ (5.3\%) while a $10 \mathrm{db}$ increase in noise depreciates land prices (house prices) by 5\% (1.25\%). If not estimated conditional on each other, these effects are underestimated by as much as $40 \%$ and more. At stations, the countervailing effects just about offset each other. These effects are estimated using a pre-trend weighted (PTW) difference-indifference (DD) estimator, which unlike other matching techniques minimizes the conditional correlation of various continuous treatment variables with trends in the outcome variable before the intervention. As an over-identification test, we estimate the noise effect exploiting discontinuous variation in changes in noise over time at a tunnel entrance where the elevated line switches to becoming an underground line and vice versa. The regression discontinuity design (RDD) estimates are closely in line with the RDD estimates.

We complement the historic analysis of rail effects with a cross-sectional hedonic analysis of station distance and rail noise capitalization effects using property transaction data from the past two decades. A comparison of the historic estimates to our contemporary analysis and recent estimates from the literature suggests that rail accessibility effects have remained remarkably constant over more than a century, suggesting a fairly stable time-preference rate. In contrast, the noise effects have increased substantially, which is in line with increasing preferences for environmental quality.

Due to this increased disamenity aversion, the welfare case for constructing underground rail lines in a dense urban setting is significantly stronger today than at the times when the Line A was constructed. While based on our historic noise capitalization estimate the implied aggregated land value effect corresponds to a fraction of the extra cost for an underground line, costs and local benefits roughly equate if contemporary noise is taken as a basis. Additional wider benefits to visitors and tourists likely imply a positive welfare case.

Our estimates also imply a significant equity case for underground lines as elevated rail lines are associated with significant localized disamenity effects which, assuming contemporary noise effects, can more than compensate for accessibility gains. Potential contributions by landlords, if considered as a source of revenue to finance metro rail projects, would need to take into account positive accessibility and negative noise effects, which complicates the implementation in practice. Back-of-the-envelope calculations suggest that at today's rate of noise capitalization it is possible to recover extra costs for constructing underground lines over the lifetime of a project, which rationalizes the shift away from the construction of elevated lines and towards underground lines over the course of the $20^{\text {th }}$ century. 


\section{Literature}

Abadie, A., \& Gardeazabal, J. (2003). The Economic Costs of Conflict: A Case Study of the Basque Country. American Economic Review, 93(1), 113-132. doi:doi: $10.1257 / 000282803321455188$

Ahlfeldt, G. M., \& Maennig, W. (2015). Homevoters vs. leasevoters: A spatial analysis of airport $\begin{array}{lllll}\text { effects. Journal of Urban 85-99. } & \end{array}$ doi:http://dx.doi.org/10.1016/j.jue.2015.03.002

Ahlfeldt, G. M., Moeller, K., \& Wendland, N. (2015). Chicken or egg? The PVAR econometrics of transportation. Journal of Economic Geography, 15(6), 1169-1193. doi:10.1093/jeg/lbu037

Ahlfeldt, G. M., Redding, S. J., Sturm, D. M., \& Wolf, N. (2015). The Economics of Density: Evidence from the Berlin Wall. Econometrica, 83(6), 2127-2189.

Al-Mosaind, M. A., Dueker, K. J., \& Strathman, J. G. (1993). Light-Rail Transit Stations and Property Values: A Hedonic Price Approach. Transportation Research Record, 1400, 90-94.

Alonso, W. (1964). Location and land use. Cambridge, MA: Harvard.

Angrist, J. D., \& Pischke, J.-S. (2009). Mostly Harmless Econometrics: An Empiricist's Companion. Princeton, New Jersey: Princton University Press.

Ashenfelter, O., \& Card, D. (1985). Using the Longitudinal Structure of Earnings to Estimate the Effect of Training Programs. The Review of Economics and Statistics, 67(4), 648-660.

Bajic, V. (1983). The Effects of a New Subway Line on Housing Prices in Metropolitan Toronto. Urban Studies, 20(2), 147-158.

Baltzer, F. (1897). Die elektrische Stadtbahn in Berlin von Siemens \& Halske. Zeitschrift für Kleinbahnen.

Banerjee, A., Duflo, E., \& Qian, N. (2012). On the Road: Access to Transportation Infrastructure and Economic Growth in China. NBER Working Paper 17897.

Bartholomew, K., \& Ewing, R. (2011). Hedonic Price Effects of Pedestrian- and Transit-Oriented

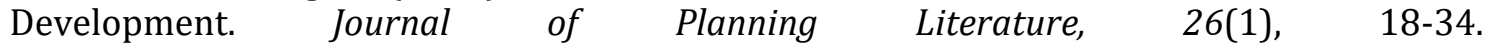
doi:10.1177/0885412210386540

Basten, C., \& Betz, F. (2013). Beyond Work Ethic: Religion, Individual, and Political Preferences. American Economic Journal: Economic Policy, 5(3), 67-91. doi:doi: 10.1257/pol.5.3.67

Baum-Snow, N. (2007). Did Highways Cause Suburbanization? The Quarterly Journal of Economics, 122(2), 775-805. doi:10.1162/qjec.122.2.775

Baum-Snow, N., \& Kahn, M. E. (2000). The effects of new public projects to expand urban rail transit. Journal of Public Economics, 77(2), 241-263.

Baum-Snow, N., Loren Brandt, J., Henderson, J. V., Turner, M. A., \& Zhang, Q. (2012). Roads, Railroads and Decentralization of Chinese Cities. Working Paper.

Berry, B. J. L. (1976). Ghetto Expansion and Single-Family Housing Prices. Journal of Urban Economics, 3(4), 397-423.

Bertrand, M., Duflo, E., \& Mullainathan, S. (2004). How much should we trust difference-indifference estimates? The Quarterly Journal of Economics, 119(1), 249-275.

Billings, S. B. (2011). Estimating the value of a new transit option. Regional Science and Urban Economics, 41(6), 525-536. doi:http://dx.doi.org/10.1016/i.regsciurbeco.2011.03.013

Boes, S., \& Nüesch, S. (2011). Quasi-experimental evidence on the effect of aircraft noise on apartment rents. Journal of Urban Economics, 69(2), 196-204. doi:http://dx.doi.org/10.1016/j.jue.2010.09.007

Bousset, E. H. J. (1935). Die Berliner U-Bahn. Berlin: Wilhem Ernst \& Sohn.

Bowes, D. R., \& Ihlanfeldt, K. R. (2001). Identifying the Impacts of Rail Transit Stations on Residential Property Values. Journal of Urban Economics, 50(1), 1-25.

Chay, K. Y., \& Greenstone, M. (2005). Does Air Quality Matter? Evidence from the Housing Market. Journal of Political Economy, 113(2), 376-424.

Coffman, C., \& Gregson, M. (1998). Railroad Development and Land Value. Journal of Real Estate Finance \& Economics, 16(2), 191-204.

Combes, P.-P., Duranton, G., \& Gobillon, L. (2013). The Costs of Agglomeration: Land Prices in French Cities. Paris School of Economics Working Paper No 2013 - 28.

Damm, D., Lerner-Lam, E., \& Young, J. (1980). Response of Urban Real Estate Values in Anticipation of the Washington Metro. Journal of Transport Economics and Policy, 14(3), 315-336. 
Davis, L. W. (2004). The Effect of Health Risk on Housing Values: Evidence from a Cancer Cluster. American Economic Review, 94(5), 1693-1704. doi:10.1257/0002828043052358

Debrezion, G., Pels, E., \& Rietveld, P. (2007). The Impact of Railway Stations on Residential and Commercial Property Value: A Meta-analysis. Journal of Real Estate Finance \& Economics, 35(2), 161-180.

Debrezion, G., Pels, E., \& Rietveld, P. (2010). The Impact of Rail Transport on Real Estate Prices: An Empirical Analysis of the Dutch Housing Market. Urban Studies. doi:10.1177/0042098010371395

Dell, M. (2010). The Persistent Effects of Peru's Mining Mita. Econometrica, 78(6), 1863-1903. doi:10.3982/ecta8121

Dewees, D. N. (1976). The Effect of a Subway on Residential Property Values in Toronto. Journal of Urban Economics, 3(4), 357.

Domke, P., \& Hoeft, M. (1998). Tunnel, Gräben, Viadukte: 100 Jahre Baugeschichte der Berliner UBahn. Berlin: Kulturbild Verlag.

Donaldson, D. (2015). Railroads of the Raj: Estimating the Impact of Transportation Infrastructure. American Economic Review, forthcoming.

Dubé, J., Thériault, M., \& Des Rosiers, F. (2013). Commuter rail accessibility and house values: The case of the Montreal South Shore, Canada, 1992-2009. Transportation Research Part A: Policy and Practice, 54, 49-66. doi:http://dx.doi.org/10.1016/i.tra.2013.07.015

Duranton, G., Morrow, P. M., \& Turner, M. A. (2013). Roads and Trade: Evidence from the US. The Review of Economic Studies, online first. doi:10.1093/restud/rdt039

Duranton, G., \& Turner, M. A. (2012). Urban Growth and Transportation. The Review of Economic Studies, 79(4), 1407-1440. doi:10.1093/restud/rds010

Epple, D., Gordon, B., \& Sieg, H. (2010). A New Approach to Estimating the Production Function for Housing. American Economic Review, 100(3), 905-924. doi:doi: 10.1257/aer.100.3.905

Erbe, M. (1987). Berlin im Kaiserreich. In W. Ribbe (Ed.), Geschichte Berlins. Munich: C.H. Beck.

Fama, E. F. (1970). Efficient Capital Markets: A Review of Theory and Empirical Work. The Journal of Finance, 25(2), 383-417.

Fischel, W. A. (2001). Why Are There NIMBYs? Land Economics, 77(1), 144-152. doi: $10.2307 / 3146986$

Flyvbjerg, B., Bruzelius, N., \& van Wee, B. (2008). Comparison of Capital Costs per RouteKilometre in Urban Rail. European Journal of Transport and Infrastructure Research, 8(1), 17-30.

Gatzlaff, D. H., \& Smith, M. T. (1993). The Impact of the Miami Metrorail on the Value of Residences Near Station Locations. Land Economics, 69(1), 54-66.

Gibbons, S. (2015). Gone with the wind: Valuing the visual impacts of wind turbines through house prices. Journal of Environmental Economics and Management, 72, 177-196. doi:http://dx.doi.org/10.1016/j.jeem.2015.04.006

Gibbons, S., \& Machin, S. (2005). Valuing rail access using transport innovations. Journal of Urban Economics, 57(1), 148-169.

Gibbons, S., \& Machin, S. (2008). Valuing school quality, better transport, and lower crime: evidence from house prices. Oxford Review of Economics, 24(1), 99-119.

Gibbons, S., Machin, S., \& Silva, O. (2013). Valuing school quality using boundary discontinuities. Journal of Urban Economics, 75(0), 15-28. doi:http://dx.doi.org/10.1016/i.jue.2012.11.001

Greenstone, M., \& Gallagher, J. (2008). Does Hazardous Waste Matter? Evidence from the Housing Market and the Superfund Program. The Quarterly Journal of Economics, 123(3), 951-1003. doi:10.1162/qjec.2008.123.3.951

Harrison, D. J., \& Rubinfeld, D. L. (1978). Hedonic housing prices and the demand for clean air. Journal of Environmental Economics and Management, 5(1), 81-102. doi:http://dx.doi.org/10.1016/0095-0696(78)90006-2

Hilber, C. A. L., \& Vermeulen, W. (2015). The Impact of Supply Constraints on House Prices in England. The Economic Journal, n/a-n/a. doi:10.1111/ecoj.12213

Hurst, N. B., \& West, S. E. (2014). Public transit and urban redevelopment: The effect of light rail transit on land use in Minneapolis, Minnesota. Regional Science and Urban Economics, 46, 57-72. doi:http://dx.doi.org/10.1016/i.regsciurbeco.2014.02.002

Iacus, S. M., King, G., \& Porro, G. (2011). Multivariate Matching Methods That Are Monotonic Imbalance Bounding. Journal of the American Statistical Association, 106(493), 345-361. doi:10.1198/jasa.2011.tm09599 
Imbens, G. W., \& Lemieux, T. (2008). Regression discontinuity designs: A guide to practice. Journal of Econometrics, 142(2), 615-635.

Kau, J. B., \& Sirmans, C. F. (1979). Urban Land Value Functions and the Price Elasticity of Demand for Housing. Journal of Urban Economics, 6(1), 112.

Lalive, R. (2008). How do extended benefits affect unemployment duration? A regression discontinuity approach. Journal of Econometrics, 142(2), 785-806. doi:http://dx.doi.org/10.1016/i.jeconom.2007.05.013

Leggett, C. G., \& Bockstael, N. E. (2000). Evidence of the Effects of Water Quality on Residential Land Prices. Journal of Environmental Economics and Management, 39(2), 121-144. doi:http://dx.doi.org/10.1006/jeem.1999.1096

Linden, L., \& Rockoff, J. E. (2008). Estimates of the Impact of Crime Risk on Property Values from Megan's Laws. American Economic Review, 98(3), 1103-1127. doi:10.1257/aer.98.3.1103

McDonald, J. F., \& Bowman, H. W. (1979). Land value functions: A reevaluation. Journal of Urban Economics, 6(1), 25-41.

McDonald, J. F., \& Osuji, C. I. (1995). The effect of anticipated transportation improvement on residential land values. Regional Science \& Urban Economics, 25(3), 261.

McMillen, D. P. (1996). One Hundred Fifty Years of Land Values in Chicago: A Nonparametric Approach. Journal of Urban Economics, 40(1), 100-124.

McMillen, D. P. (2004). Airport expansions and property values: the case of Chicago O'Hare Airport. Journal of Urban Economics, 55(3), 627-640. doi:http://dx.doi.org/10.1016/j.jue.2004.01.001

McMillen, D. P., \& McDonald, J. F. (2002). Land Values in a Newly Zoned City. The Review of Economics and Statistics, 84(1), 62-72.

McMillen, D. P., \& McDonald, J. F. (2004). Reaction of House Prices to a New Rapid Transit Line: Chicago's Midway Line, 1983-1999. Real Estate Economics, 32(3), 463-486.

Mieszkowski, P., \& Saper, A. M. (1978). An Estimate of the Effects of Airport Noise on Property Values. Journal of Urban Economics, 5(4), 425-440.

Mills, E. S. (1967). An Aggregative Model of Resource Allocation in a Metropolitan Centre. American Economic Review, 57(2), 197-210.

Mills, E. S. (1969). The value of urban land. In H. Perloff (Ed.), The quality of urban environment. Baltimore, MA: Resources for the Future, Inc.

Muth, R. (1969). Cities and Housing. Chicago: University of Chicago Press.

Nelson, A. C. (1992). Effects of Elevated Heavy-Rail Transit Stations on House Prices with Respect to Neighborhood Income. Transportation Research Record, 1359, 127-132.

Nelson, J. P. (1978). Residential choice, hedonic prices, and the demand for urban air quality. Journal of Urban Economics, 5(3), 357-369.

Nelson, J. P. (2004). Meta-Analysis of Airport Noise and Hedonic Property Values: Problems and Prospects. Journal of Transport Economics \& Policy, 38(1), 1-28.

Oates, W. E. (1969). The Effects of Property Taxes and Local Public Spending on Property Values: An Empirical Study of Tax Capitalization and the Tiebout Hypothesis. Journal of Political Economy, 77(6), 957-971.

Osborne, M. J., \& Turner, M. A. (2010). Cost benefit analyses versus referenda. Journal of Political Economy, 118(1), 156-187.

Phillips, D. C., \& Sandler, D. (2015). Does public transit spread crime? Evidence from temporary rail station closures. Regional Science and Urban Economics, 52, 13-26. doi:http://dx.doi.org/10.1016/j.regsciurbeco.2015.02.001

Pope, J. C. (2008). Buyer information and the hedonic: The impact of a seller disclosure on the implicit price for airport noise. Journal of Urban Economics, 63(2), 498-516. doi:http://dx.doi.org/10.1016/i.jue.2007.03.003

Rosen, S. (1974). Hedonic Prices and Implicit Markets: Product Differentiation in Pure Competition. Journal of Political Economy, 82(1), 34-55.

Rosenbaum, P. R., \& Rubin, D. B. (1983). The Central Role of the Propensity Score in Observational Studies for Causal Effects. Biometrika, 70(1), 41-55. doi:10.2307/2335942

Rossi-Hansberg, E., Sarte, P.-D., \& Owens, R. (2010). Housing Externalities. Journal of Political Economy, 118(3), 485-535.

Senatsverwaltung für Stadtentwicklung Berlin. (2006). Urban and Environmental Information System. Berlin.

Silverman, B. W. (1986). Density Estimation For Statistics and Data Analysis. Monographs on Statistics and Applied Probability. 
Tyrväinen, L., \& Miettinen, A. (2000). Property Prices and Urban Forest Amenities. Journal of Environmental Economics and Management, 39(2), 205-223. doi:http://dx.doi.org/10.1006/jeem.1999.1097

Voith, R. (1993). Changing Capitalization of CBD-Oriented Transportation Systems: Evidence from Philadelphia, 1970-1988. Journal of Urban Economics, 33(3), 361.

Wrigley, M., \& Wyatt, P. (2001). Transport Policy and Property Values. Paper presented at the Royal Institution of Chartered Surveyors (RICS) 'Cutting Edge' Conference, University of the West of England.

$\mathrm{Xu}$, Y., Zhang, Q., \& Zheng, S. (2015). The rising demand for subway after private driving restriction: Evidence from Beijing's housing market. Regional Science and Urban Economics, 54, 28-37. doi:http://dx.doi.org/10.1016/j.regsciurbeco.2015.06.004

Yeates, M. H. (1965). Some Factors Affecting the Spatial Distribution of Chicago Land Values, 1910-1960. Economic Geography, 41(1), 57-70. 